\title{
Metrical structure in Scottish Gaelic: Tonal accent, glottalisation and overlength
}

DOI:

10.1017/S0952675719000204

\section{Document Version}

Accepted author manuscript

Link to publication record in Manchester Research Explorer

\section{Citation for published version (APA):}

Morrison, D. (2019). Metrical structure in Scottish Gaelic: Tonal accent, glottalisation and overlength. Phonology, 36(3). https://doi.org/10.1017/S0952675719000204

\section{Published in:}

Phonology

\section{Citing this paper}

Please note that where the full-text provided on Manchester Research Explorer is the Author Accepted Manuscript or Proof version this may differ from the final Published version. If citing, it is advised that you check and use the publisher's definitive version.

\section{General rights}

Copyright and moral rights for the publications made accessible in the Research Explorer are retained by the authors and/or other copyright owners and it is a condition of accessing publications that users recognise and abide by the legal requirements associated with these rights.

\section{Takedown policy}

If you believe that this document breaches copyright please refer to the University of Manchester's Takedown Procedures [http://man.ac.uk/04Y6Bo] or contact uml.scholarlycommunications@manchester.ac.uk providing relevant details, so we can investigate your claim.

\section{OPEN ACCESS}




\section{Metrical structure in Scottish Gaelic: Tonal accent, glottalisation and overlength}

\section{Introduction}

In several languages of northern Europe, words may display a suprasegmental contrast associated with the stressed syllable that manifests itself through differences in pitch, phonation, duration or a combination thereof. For example, Swedish and Norwegian display two distinctive tonal accents, Accent 1 and Accent 2, while the cognate opposition in Danish is realised by a form of glottalisation known as stød (Gårding 1977). Similarly, some Franconian dialects contrast two tonal accents accompanied by differences in duration (Gussenhoven \& Peters 2004; Peters 2006). Meanwhile, heavy stressed syllables in Estonian distinguish both normal length and overlength, each with its own characteristic pitch contour (Lehiste 1960). As noted by Ternes (1980; 2006: ch. 5), a microcosm of these phenomena is found in Scottish Gaelic, where forms belonging to two phonological classes-termed Class 1 (C1) and Class 2 (C2) in this paper-are distinguished in different dialects by means of either tonal accent, glottalisation or overlength. Tonal accent is used in Lewis (Borgstrøm 1940; Oftedal 1956), glottalisation in Islay (Holmer 1938), and overlength in Applecross, Ross-shire (Borgstrøm 1941; Ternes 1973):

Lewis Islay Applecross

a. C1:

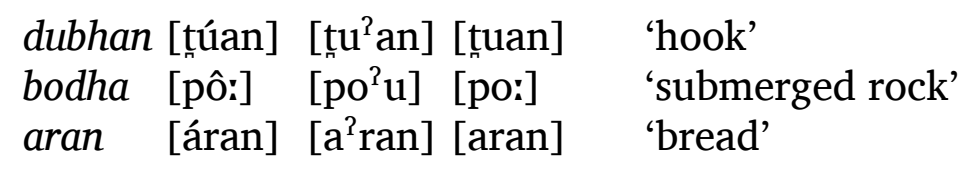

b. C2:

$\begin{array}{lllll}\text { uan } & \text { [uán] } & \text { [uan] } & \text { [ua'n] } & \text { 'lamb' } \\ \text { bò } & \text { [pǒ:] } & \text { [pou] } & \text { [po:'] } & \text { 'cow' } \\ \text { arm } & \text { [arám] [arəm] } & \text { [ara'm] } & \text { 'army' }\end{array}$

In Lewis, $\mathrm{C} 1$ forms display a pitch peak on the first mora and C2 forms on the second. Meanwhile, in Islay, C1 forms are distinguished from C2 forms 
by a period of glottalisation between the first two morae. Finally, in Applecross, $\mathrm{C} 1$ forms show normal length while $\mathrm{C} 2$ forms exhibit overlength through elongation of the second mora.

It has long been argued that the contrast between long and overlong syllables in Estonian reflects a difference in the extent of the foot (Prince 1980; Odden 1997), and a number of recent analyses have likewise invoked metrical structure in order to derive the tonal accent contrasts in Swedish (Morén-Duolljá 2013) and Franconian (Köhnlein 2011; 2016; 2017; 2018; Hermans 2012; Kehrein 2017; van Oostendorp 2017), as well as Danish stød (Iosad 2016). The contrast between C1 and C2 forms in Scottish Gaelic has also been ascribed to metrical structure in various ways, sometimes involving complex multi-layered structures such as "super-syllables" (Bosch \& de Jong 1998) or recursive syllables (Smith 1999). In accordance with numerous other authors (Oftedal 1956; Hind 1996; 1997; Ladefoged et al. 1998; Hall 2003; 2006; Ladefoged 2003; Wentworth 2005; Iosad 2015), I argue that the contrast directly reflects the extent of the stressed syllable: specifically, in $\mathrm{C} 1$ forms, the stressed syllable contains only the first mora while in C2 forms it contains the first two. Unlike most of the aforementioned analyses of other languages, however, I will argue that the metrical structure-and hence the phonological class membership-of a form in Scottish Gaelic is predictable from its underlying segmental content: in other words, the metrical contrast between $\mathrm{C} 1$ and $\mathrm{C} 2$ forms is a derived one. Scottish Gaelic can therefore be thought of as representing an intermediate step on the diachronic trajectory that historically led to the lexically contrastive metrical structure proposed for those languages in the present day.

The analysis presented in this paper uses the framework of Stratal Optimality Theory (Kiparsky 2000; Bermúdez-Otero 2018), according to which an utterance undergoes several rounds of phonological computation acting upon successively larger morphosyntactic domains, viz. the stem, the word and the phrase. I argue that metrical structure in Scottish Gaelic is built in the stem-level phonology in a regular manner, but may subsequently be rendered opaque by segmental operations at the word level-in particular, a process of copy epenthesis known as svarabhakti, which creates syllables containing two vocalic sonority peaks. In this way, the present analysis is similar to van Oostendorp's (2017) analysis of tonal accent on pre-obstruent short vowels in Moresnet Franconian. Drawing on the proposals of Köhnlein $(2016 ; 2018)$ for Franconian tonal accent, I claim that 
faithfulness to foot structure preserves the stem-level syllable count when svarabhakti occurs, resulting in a word-level contrast between disyllabic and monosyllabic feet-even in sequences with identical segmental content. These differing metrical structures are then reflected on the surface by means of either tonal accent, glottalisation or overlength depending on dialect.

This paper demonstrates the ability of Stratal Optimality Theory to account for the highly complex intricacies of Scottish Gaelic phonology in a principled manner, and aims to provide the most complete and thorough analysis to date of the C1-C2 contrast in Scottish Gaelic. Additionally, by demonstrating how the same surface metrical contrast may be realised in different dialects of a single language by means of either tonal accent, glottalisation or overlength, this paper hopes to bring closer together the various existing metrical analyses of these phenomena in languages such as Swedish, Danish, Franconian and Estonian.

\subsection{Sources and transcription}

A considerable amount of dialectal variation exists in Scottish Gaelic and it is necessary to limit any detailed analysis to a single variety. This paper will focus primarily upon the dialect of Lewis in the Outer Hebrides, where the C1-C2 contrast is realised through tonal accent. When not stated otherwise, all forms cited in this paper are from this dialect. Within Lewis, Borgstrøm (1940) provides a detailed description of the dialect of Bernera in the west of the island, as well as some additional notes on that of Ness in the far north, while Oftedal (1956) describes in detail the dialect of Leurbost in the east of the island. As far as possible, the Lewis forms cited in this paper are limited to those found either in those two sources or in Ladefoged et al. (1998), which revisits the dialect of Bernera; however, they are occasionally supplemented by forms from the Survey of the Gaelic Dialects of Scotland (SGDS; Ó Dochartaigh 1994-1997) or from my own fieldwork in Ness. When a generalisation is made over all of the Lewis data, this should be taken to encompass all Lewis forms cited in Borgstrøm (1940), Oftedal (1956) and Ladefoged et al. (1998) to the exclusion of compound forms, on which too little data is available for any systematic treatment, and transparent English or Scots loans, which do not always display full assimilation into the phonological system of Scottish Gaelic. 
Due to the diverse transcription practices employed by the various sources cited in this paper, a large amount of normalisation has been necessary. Although the forms cited here may therefore differ considerably from those in my sources both in terms of the symbols employed and the degree of phonetic detail included, I have endeavoured throughout to accurately mark all aspects of their pronunciation that are relevant to the present analysis. All symbols have their IPA values except for the coronal sonorants, for which a more abstract notation is employed (see next section). English glosses have also been normalised in order to facilitate cross-dialectal comparison of cognate forms.

\subsection{Slenderisation and the fortis-lenis contrast}

Before we proceed with the analysis, it is necessary to introduce two important aspects of the sound system of Scottish Gaelic. For a general overview of the Scottish Gaelic sound system, the reader may wish to consult handbook chapters by MacAulay (1992), Gillies (2009) or Bosch (2010). First of all, following traditional terminology, coronal and dorsal consonants in Scottish Gaelic may be either broad (non-palatalised) or slender (palatalised). Numerous morphological categories, such as genitive case in many nouns and comparative degree in adjectives, are marked by means of a morphophonological process known as slenderisation, which targets the stem-final rhyme and converts broad consonants into their slender counterparts. If the stem is monosyllabic, slenderisation is often accompanied by an alternation in the vowel which I will refer to as ablaut.

Secondly, again following traditional terminology, sonorants may be either fortis or lenis. The set of fortis sonorants $\left[\mathrm{m} \mathrm{N} \mathrm{N}^{\mathrm{j}} \mathrm{L} \mathrm{L}^{\mathrm{j}} \mathrm{R}\right]$ may be precisely defined as those which may freely occur in initial position in unmutated stems, while the remaining sonorants $\left[\mathrm{n}^{\mathrm{j}} \mathrm{r} \mathrm{r}^{\mathrm{j}}\right]$ 一which normally occur initially only as a result of the lenition mutation-are lenis. The fortis coronal sonorants $/ \mathrm{N} \mathrm{N}^{\mathrm{j}} \mathrm{L} \mathrm{L} \mathrm{R}^{\mathrm{j}} /$ are equivalent to IPA $/ \mathrm{n}^{\mathrm{y}} \mathrm{n} \underline{n}^{\mathrm{\gamma}} \hat{\mathrm{S}} \mathrm{r}^{\mathrm{y}} /$ respectively, and the lenis coronal sonorants $/ \mathrm{n}^{\mathrm{j}} \mathrm{r} \mathrm{r}^{\mathrm{j}} /$ to IPA $/ \mathrm{n}^{\mathrm{j}}$ г $\mathrm{\partial}^{\mathrm{j}} /$; however, I will follow Celticist tradition and employ the former, more abstract notation throughout this paper in order to emphasise the phonological relationships that exist between these sounds. Note that both broad fortis [N] and broad lenis $[\mathrm{n}]$ alternate with slender fortis $\left[\mathrm{N}^{\mathrm{j}}\right]$ under slenderisation:

$$
\text { a. }\left[\mathrm{N} \sim \mathrm{N}^{\mathrm{j}}\right]
$$




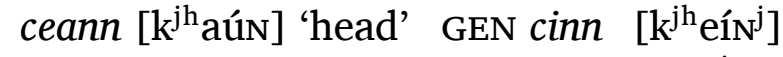
b. $\left[n \sim N^{j}\right]$
fonn [fJúN] 'tune' GEN fuinn [fəín']
eun [ián] 'bird' GEN eòin [ị̌:s'j]

Note also that broad fortis $[\mathrm{L}]$ may alternate with either slender fortis $\left[\mathrm{L}^{\mathrm{j}}\right]$ or slender lenis $\left[\mathrm{l}^{\mathrm{j}}\right]$ under slenderisation:
a. $\left[\mathrm{L} \sim \mathrm{L}^{\mathrm{j}}\right]:$

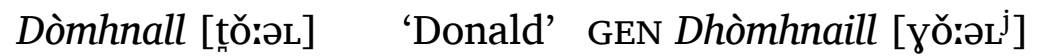

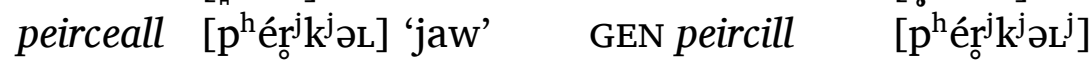

b. $\left[\mathrm{L} \sim \mathrm{l}^{\mathrm{j}}\right]$ :

\begin{tabular}{|c|c|c|c|}
\hline & & 'devil' & GEN diabhail \\
\hline saoghal & [șǔ:vəL] & 'world' & GEN saoghail \\
\hline
\end{tabular}

I take these alternations to indicate the existence of word-level fortition processes that convert certain underlyingly lenis coronal sonorants into fortis ones, resulting in the absence of slender lenis * $\left[\mathrm{n}^{j}\right]$ and broad lenis *[1] on the surface. I will assume that fortis $\left[\mathrm{N}^{j}\right]$ and $[\mathrm{L}]$ represent underlyingly lenis sonorants whenever they are seen to alternate with lenis [n] and $\left[\mathrm{l}^{\mathrm{j}}\right]$ respectively. Throughout the present paper, slenderisation alternations will occasionally be used in examples to show that a particular instance of $\left[\mathrm{N}^{\mathrm{j}}\right]$ or $[\mathrm{L}]$ is underlyingly lenis.

The structure of the paper is as follows. 22 shows that the $\mathrm{C} 1-\mathrm{C} 2$ contrast directly reflects the extent of the stressed syllable, and establishes the surface metrical structure of various types of C1 and C2 forms. It is shown that, in most cases, this follows from surface segmental content. §3 argues that the remaining cases-containing monosyllabic sequences with two vocalic sonority peaks-result from a regular phonological process of copy epenthesis known as svarabhakti. $\S 4$ argues that svarabhakti is a word-level process that depends on a mora projected by a coda sonorant at the stem level, and establishes the stem-level outputs upon which svarabhakti acts, while $\S 5$ offers an Optimality Theoretic account of svarabhakti, showing how faithfulness to input foot structure can bring about the observed monosyllabic sequences. $§ 6$ discusses how the differing metrical structures of C1 and C2 forms are realised on the surface in different dialects of Scottish Gaelic. §7 provides some general discussion and §8 concludes the paper. 


\section{Surface metrical structure}

Almost all non-compound content words in Scottish Gaelic bear initial stress. No secondary stress occurs except in synchronic compound forms, which will not be considered here since too little data is available for any systematic treatment of words of this type. In most cases, whether a form belongs to $\mathrm{C} 1$ or C2 simply depends on the length of the stressed vowel: if the stressed vowel is short then the form belongs to $\mathrm{C} 1$, realised in Lewis with a pitch peak on the first mora of the word, and if the stressed vowel is long then it belongs to $\mathrm{C} 2$, with a peak on the second mora. More generally, the pitch peak can thus be said to occur on the rightmost mora of the stressed vowel. However, under certain circumstances, the phonological class of a form may not follow straightforwardly from its overt surface segmental content. This can result in minimal pairs:

(4)

\begin{tabular}{lll} 
C1: & \multicolumn{2}{c}{ C2: } \\
dubhan [țúan] & 'hook' & duan [tuán] 'poem' \\
bodha [pô:] & 'submerged rock' bò [pǒ:] 'cow' \\
ballag [pátak] 'skull' & balg [paLák] 'bag'
\end{tabular}

In this section I show that the $\mathrm{C} 1-\mathrm{C} 2$ contrast directly reflects the extent of the stressed syllable in forms such as those in (4). I provide independent evidence that in $\mathrm{C} 1$ forms - which bear the first-mora pitch peak typical of a short stressed vowel - the stressed syllable contains only the first mora of the word, while in $\mathrm{C} 2$ forms - which bear the second-mora peak typical of a long stressed vowel-it contains the first two. This in turn leads to a difference in foot structure: in $\mathrm{C} 1$ forms the foot consists of two monomoraic syllables, while in C2 forms it consists of one dimoraic syllable. This section will build upwards through the prosodic hierarchy from the mora in $\S 2.1$, through the syllable in $\S 2.2$, to the foot in $\S 2.3$, in order to establish the surface metrical structure of the various types of $\mathrm{C} 1$ and $\mathrm{C} 2$ forms illustrated in (4).

\subsection{The mora}

I will assume that onset consonants are attached directly to the syllable node while coda consonants may either head a mora of their own, in which case they contribute to syllable weight, or else attach to the nearest mora 
to their left, in which case they are weightless (Hayes 1989; Broselow et al. 1997). Geminate consonants are overtly moraic; otherwise, moraic consonants may be diagnosed in codas whenever VC rhymes are seen to pattern with VV rhymes in some way, e.g. by attracting stress (as in Latin) or satisfying a word-minimality condition (as in English). Smith (1999: 618) and Hall (2003: 109) claim that evidence of the latter type exists in Lewis Gaelic, citing a process of final $h$-epenthesis that affects short open monosyllables, e.g. crodh $\left[\mathrm{k}^{\mathrm{h}} \mathrm{ro}^{\mathrm{h}}\right]$ 'cattle', dubh [tun $\left.{ }^{\mathrm{h}}\right]$ 'black'. According to their analysis, $h$-epenthesis serves to satisfy a word-minimality condition by providing a monomoraic word with a coda. It follows from this that coda consonants must generally be moraic in Lewis Gaelic-at least when preceded by a short stressed vowel. However, $h$-epenthesis normally only occurs before pausa (Borgstrøm 1940: 74; Oftedal 1956: 116), which is unexpected if it serves to satisfy a general word-minimality condition. Additionally-and in agreement with Ternes (1973: 84) for Applecross, Ross-shire and Wentworth (2005: 446) for Gairloch, Ross-shire-my own observations suggest that $h$-epenthesis forms just part of a more general devoicing process that also affects all voiced coda consonants in exactly the same environment, e.g. bean [pen] 'wife', geal [k'as] 'white', and thus cannot be motivated by the need for a coda consonant ( $c f$. also the distribution of glottalisation reported by Sommerfelt 1922 for an Ulster dialect of Irish). In accordance with Green (1997) for modern Goidelic in general, I therefore believe there is no evidence that coda consonants are moraic on the surface in Lewis Gaelic-although I will claim in $\S 4$ that moraic coda consonants do occur at an intermediate stage of the phonological derivation before subsequently transferring their morae to adjacent vowels. It will also be seen that overtly moraic (i.e. geminate) coda consonants may occur on the surface in other dialects which lack these mora-transfer processes.

\subsection{The syllable}

There are three sets of circumstances under which the phonological class of a form in Lewis Gaelic may not follow straightforwardly from its overt surface segmental content. In each case, there is independent evidence that the stressed syllable contains only the first mora in $\mathrm{C} 1$ forms and the first two morae in $\mathrm{C} 2$ forms. First of all, certain ${ }^{\prime} \mathrm{V}_{i} \mathrm{~V}_{j}$ sequences (where $\mathrm{V}_{i}$ and 
$\mathrm{V}_{j}$ are two short vowels) may occur with either the first-mora pitch peak of $\mathrm{C} 1$ or the second-mora peak of $\mathrm{C} 2$ :

$$
\begin{array}{ll}
\text { (5) } \mathrm{C} 1^{\prime} \mathrm{V}_{i} \mathrm{~V}_{j} \text { : } & \mathrm{C} 2{ }^{\prime} \mathrm{V}_{i} \mathrm{~V}_{j} \text { : } \\
\text { dubhan [túan] 'hook' } & \text { duan [țaán] 'poem' } \\
\text { fitheach [fíəx] 'raven' } & \text { fiach [fióx] 'value' } \\
\text { meadhan [mían] 'middle' eun [ián] 'bird' } \\
\text { ubhal [úoL] 'apple' gual [kuás] 'coal' }
\end{array}
$$

There is evidence that $C 1{ }^{\prime} \mathrm{V}_{i} \mathrm{~V}_{j}$ sequences are hiatus sequences and $\mathrm{C} 2{ }^{\prime} \mathrm{V}_{i} \mathrm{~V}_{j}$ sequences are diphthongs. Phonotactically, a $C 1{ }^{\prime} V_{i} V_{j}$ sequence may generally contain any vowel that is allowed in a stressed syllable followed by any vowel that is allowed in an unstressed syllable; on the other hand, C2 ${ }^{\prime} \mathrm{V}_{i} \mathrm{~V}_{j}$ sequences are restricted to certain pairs of vowels, viz. [iá iá uá uá] and various combinations ending in [í] or [ú]. Additionally, $\mathrm{C} 2{ }^{\prime} \mathrm{V}_{i} \mathrm{~V}_{j}$ sequences behave as if monosyllabic under slenderisation. Recall from $\$ 1.2$ that slenderisation may be accompanied by vowel ablaut in monosyllabic stems. Under slenderisation, $C 2{ }^{\prime} \mathrm{V}_{i} \mathrm{~V}_{j}$ sequences frequently undergo ablaut alternations with long vowels:

(6) feur [fiár] 'grass' GEN feòir [fì̃̀:rij] iasg [iásk] 'fish' GEN èisg [ě:: $\mathrm{k}^{\mathrm{j}}$ ]

Accordingly, I will consider a $\mathrm{C} 1{ }^{\prime} \mathrm{V}_{i} \mathrm{~V}_{j}$ sequence to consist of two vowels in hiatus, so that only the first mora belongs to the stressed syllable; meanwhile, I will consider a $\mathrm{C} 2{ }^{\prime} \mathrm{V}_{i} \mathrm{~V}_{j}$ sequence to represent a diphthong, so that the stressed syllable contains the first two morae. We can therefore uphold the generalisation that the stressed syllable is monomoraic in C1 forms, e.g. dubhan $\left.\left[\sigma \mathrm{t}^{\mathrm{n}_{\mu}}\right] \mathrm{\sigma}_{\sigma} \mathrm{a}_{\mu} \mathrm{n}\right]$ 'hook', and dimoraic in C2 forms, e.g. duan $\left[\sigma \mathrm{tu}_{\mu} \mathrm{a}_{\mu} \mathrm{n}\right]$ 'poem'.

Secondly, a word-final long vowel may occur in some dialects with the first-mora pitch peak of $\mathrm{C} 1$ rather than the second-mora peak of C2:

(7) C1 long vowels:

bodha [pô:] 'submerged rock'

latha [Lâ:] 'day'

ogha [ồ:] 'grandchild'

rubha [Rû:] 'promontory' 
There is evidence that C1 long vowels are actually hiatus sequences. Forms of this type generally exist in free variation with forms containing a straightforward hiatus sequence of a short vowel + [ə], e.g. [póə], and only the latter allomorph occurs under suffixation:
(8)
latha [Lâ:] 'day'
PL lathaichean [Láə- $\mathrm{x}^{\mathrm{j} \partial \mathrm{j}}$ ]
ogha [ô:] 'grandchild'
PL oghaichean [ว́ə-xंən]

Accordingly, I will consider a C1 long vowel to simply be a special case of hiatus in which an optional word-level phonological process has caused underlying word-final / $/$ / to assimilate in quality an immediately preceding short stressed vowel. Again, we can therefore uphold the generalisation that the stressed syllable is monomoraic in C1 forms, e.g. bodha $\left[{ }_{\sigma}\right.$ pó $\left._{\mu}\right]\left[\begin{array}{l}\sigma_{\mu} \\ \mathrm{o}_{\mu}\end{array}\right]$ 'submerged rock'.

For the phonological representation of hiatus sequences I take an approach expanding on that of Clements (1986) and assume that all apparently empty onsets in Scottish Gaelic actually contain an underspecified consonant $\left[\mathrm{X}^{(\mathrm{j})}\right]$, e.g. dubhan [țúXan] 'hook', bodha [póXo] 'submerged rock'. Similar consonants have been proposed for independent reasons in both Scottish Gaelic and Irish. Vowel-initial words in Irish select either broad or slender allomorphs of proclitic particles on a lexically specific basis, leading a number of authors to propose the existence of an initial underspecified consonant carrying secondary place features (Gussmann 1986; Ní Chiosáin 1991; Anderson 2016), and Morrison (2018a) shows that a similar representation is required for Ness Gaelic. Additionally, the distribution of broad and slender vowels in Ness Gaelic leads Morrison (2018a) to propose that a consonant of this type also occurs in hiatus. The differing syllabification of hiatus sequences on the one hand, and long vowels and diphthongs on the other, therefore follows from their surface segmental content-as with an ordinary VCV sequence, two vowels separated by $\left[\mathrm{X}^{(\mathrm{j})}\right]$ project two separate syllables, while a long vowel or diphthong projects a single syllable.

Finally, a ' $\mathrm{V}_{i} \mathrm{RV}_{i}$ sequence (where $\mathrm{V}_{i}$ is a short vowel and $\mathrm{R}$ is a sonorant) may occur with the second-mora pitch peak of $\mathrm{C} 2$ rather than the first-mora peak of $\mathrm{C1}$ :

(9) $\mathrm{C} 2{ }^{\prime} \mathrm{V}_{i} \mathrm{RV} \mathrm{V}_{i}$ :

balg [paLák] 'bag'




\begin{tabular}{|c|c|c|}
\hline crannchar & [ $\mathrm{k}^{\mathrm{h}}$ ranáxər] & 'fate' \\
\hline currcag & {$\left[\mathrm{k}^{\mathrm{h}} \mathrm{urú}{ }^{\mathrm{h}} \mathrm{kak}\right.$} & |'lapwing’ \\
\hline dorgh & [țróy] & 'fishing line' \\
\hline failm & 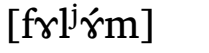 & ‘helm' \\
\hline fairrge & [faRák jəa] & 'rough sea' \\
\hline imleag & [imíljak] & 'navel' \\
\hline seanmhai & {$\left[\int \varepsilon n \operatorname{có} \mathrm{rr}^{\mathrm{j}}\right]$} & 'grandmother' \\
\hline
\end{tabular}

$\mathrm{C} 2{ }^{\prime} \mathrm{V}_{i} \mathrm{RV}_{i}$ sequences are referred to as svarabhakti groups and the second vowel is often referred to as a svarabhakti vowel. There is evidence that svarabhakti groups are in fact monosyllabic. Phonotactically, svarabhakti vowels display the full range of qualitative contrasts found in stressed syllables and are not subject to the same restrictions as unstressed vowels. Additionally, as noted by Hall (2003: 101-102; 2006: 400) and Iosad (2015: 31 ), svarabhakti groups behave as if monosyllabic under slenderisation. Recall from $\S 1.2$ that slenderisation normally targets consonants in stemfinal rhymes, and that it may be accompanied by ablaut in monosyllabic stems. If the consonant immediately following a svarabhakti group undergoes slenderisation, so does the intervening sonorant; meanwhile, ablaut affects both vowels:

(10) balg [paLák] 'bag' GEN builg [pul'úk'j] dorgh [țoróy] 'fishing line' GEN duirgh [țurjúj]

Accordingly, I will consider svarabhakti groups to be monosyllabic. Once again, we can therefore uphold the generalisation that the stressed syllable is dimoraic in C2 forms, e.g. balg [o $\mathrm{pa}_{\mu} \mathrm{La}_{\mu} \mathrm{k}$ ] 'bag'.

These syllable counts are supported by speaker intuitions at least to some extent (Borgstrøm 1937: 78; 1940: 153; Oftedal 1956: 29; Wentworth 2005: 19; Hammond et al. 2014), and are consistently reflected in poetic metre (Oftedal 1956: 29; O'Rahilly 1972: 201; Wentworth 2005: 19-20). Many other authors have reached similar conclusions, particularly with regard to svarabhakti groups (Oftedal 1956; Hind 1996; 1997; Ladefoged et al. 1998; Hall 2003; 2006; Ladefoged 2003; Wentworth 2005; Iosad 2015). Although a syllable containing a svarabhakti group therefore has a highly marked sonority profile containing two vocalic sonority peaks, Oftedal (1956: 29) points out that this is consistent with the fact that only the most sonorous consonants are allowed to intervene between the two vowels. 


\subsection{The foot}

Since words in Scottish Gaelic almost always have initial stress, I assume that every non-compound content word with non-exceptional stress contains a trochaic foot aligned with its left edge. The least marked type of trochaic foot is generally said to be one that contains either two monomoraic syllables or one dimoraic syllable (Hayes 1995; Hyde 2011), so I will assume by default that all feet (in words of two or more morae) are of this type in Scottish Gaelic. Coupled with the facts of moraic and syllabic structure established in the previous sections, this leads to the following phonological surface representations for the minimal pairs in (4): ${ }^{1}$

(11)

a. C1:

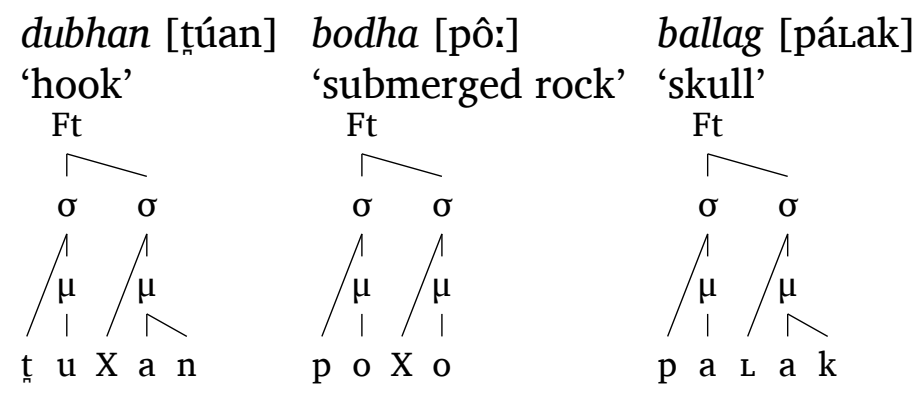

b. C2:

\begin{tabular}{|c|c|c|}
\hline duan [țuán] & bò [pǒ:] & balg [paLák] \\
\hline 'poem' & 'cow' & 'bag' \\
\hline $\mathrm{Ft}$ & $\mathrm{Ft}$ & $\mathrm{Ft}$ \\
\hline 1 & 1 & I \\
\hline$\sigma$ & $\sigma$ & $\sigma$ \\
\hline$\widehat{\mu \mu}$ & $\widehat{\mu \mu}_{\mu}$ & $\widehat{\mu}_{\mu}$ \\
\hline
\end{tabular}

Note that this now allows us to view the $\mathrm{C} 1-\mathrm{C} 2$ contrast as reflecting a difference in foot structure: in $\mathrm{C} 1$ words the foot consists of two monomoraic syllables, while in $\mathrm{C} 2$ words it consists of one dimoraic syllable.

\footnotetext{
${ }^{1}$ I assume that the intervening sonorant in a svarabhakti group attaches to the mora headed by the preceding vowel, in order to maintain the generalisation that a non-moraic consonant in the rhyme attaches to the nearest mora to its left. However, this choice has no bearing on the analysis.
} 


\section{The synchronic status of svarabhakti}

Although I argued in $\S 2.2$ that the differing syllabification of hiatus sequences on the one hand, and long vowels and diphthongs on the other, follows from their surface segmental content, the unusual syllabification of svarabhakti groups is yet to be explained. This part of the analysis argues that svarabhakti vowels are the result of a regular phonological process known as svarabhakti, which breaks up heterorganic consonant clusters whose first member is a sonorant. $\S 3.1$ discusses the regular distribution of svarabhakti vowels in Lewis Gaelic and §3.2 deals with some apparent irregularities. $\S 3.3$ discusses the manner in which svarabhakti interacts with a phenomenon of stem-internal / $/$ /-syncope in suffixed forms, and shows that the latter represents suppletive stem allomorphy.

\subsection{The distribution of svarabhakti vowels}

Virtually all phonological work on svarabhakti has either argued or assumed that svarabhakti vowels are not present underlyingly but rather are derived via either epenthesis (Ó Dochartaigh 1980; Clements 1986; Bosch 1994; Ní Chiosáin 1994; Halle 1995; Green 1997; Smith 1999; Halle et al. 2000; Iosad 2015; Stanton \& Zukoff 2018) or gestural realignment (Hind 1996; 1997; Hall 2003; 2006). The quality of the svarabhakti vowel is predictable from its environment: in Lewis it is of the same quality as the preceding vowel (Borgstrøm 1940; Oftedal 1956), in Barra it is of the same height as the preceding vowel but assimilates in backness to the intervening sonorant (Borgstrøm 1937; 1940), and in Argyll it is realised as [ə] (Holmer 1938). Normally, the svarabhakti vowel must be followed by a consonant that is heterorganic with the intervening sonorant, and for any sonorant $\mathrm{R}$ and heterorganic consonant $\mathrm{C}$ there is a complementary relationship between the circumstances under which $R$ and $C$ may surround a svarabhakti vowel and those under which they may form a cluster. The rule and some corresponding examples follow, with $\mathrm{R}, \mathrm{C}$ and any intervening svarabhakti vowel underlined in each case (note that pre-aspiration of stops is realised as devoicing of any preceding sonorant): ${ }^{2}$

\section{(12) If}

\footnotetext{
${ }^{2}$ Note that the relative syllabic affiliation of $\mathrm{R}$ and $\mathrm{C}$ is irrelevant: the rule is the same regardless of whether or not $C$ belongs to the same syllable as $R$.
} 
a. $\mathrm{R}$ is preceded by a short vowel, and

i. $\quad \mathrm{R}$ is fortis $\rightarrow$ Svarabhakti:

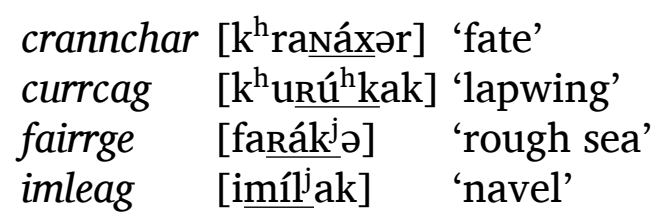

ii. $\mathrm{R}$ is lenis, and

A. C is a pre-aspirated stop $\rightarrow$ Cluster:

\begin{tabular}{|c|c|c|}
\hline cearc & {$\left[\mathrm{k}^{\mathrm{jh}} \varepsilon_{0} \mathrm{rk}\right]$} & 'hen' \\
\hline corp & [k $\mathrm{k}^{\mathrm{h}}$ órp] & 'body' \\
\hline & [óLkk] & ‘evil' (GEN uilc [úl $\left.\left.{ }_{0}^{j} k^{j}\right]\right)$ \\
\hline peirceall & {$\left[\mathrm{p}^{\mathrm{h}}\right.$ ér$\left._{0}^{\mathrm{j}} \mathrm{k}^{\mathrm{j}} \partial \mathrm{L}\right]$} & ‘jaw’ \\
\hline
\end{tabular}

B. C is not a pre-aspirated stop $\rightarrow$ Svarabhakti:

\begin{tabular}{|c|c|c|}
\hline balg & [paLák] & 'bag' (GEN builg [puljúlk $\left.{ }^{\mathrm{j}}\right]$ ) \\
\hline dorgh & [țoróx] & 'fishing line' \\
\hline & {$\left[\mathrm{f} \gamma \mathrm{l}^{\mathrm{j} \gamma \mathrm{rm}}\right]$} & 'helm' \\
\hline seanmh & {$\left[\int \varepsilon n \underline{\varepsilon}^{\prime} \operatorname{var}^{\mathrm{j}}\right]$} & 'grandmother' \\
\hline
\end{tabular}

b. $\mathrm{R}$ is preceded by a long vowel or diphthong $\rightarrow$ Cluster:

\begin{tabular}{|c|c|c|}
\hline àrc & [ă:rk] & 'cork' \\
\hline & [ě:mrəx $\left.{ }^{\mathrm{j}}\right]$ & wing' \\
\hline & [L $\mathrm{L}^{\mathrm{j}} \mathrm{u}: \underline{\text { rpost }}$ & rbost' \\
\hline ì̀rb & [miárval $\left.{ }^{\mathrm{j}}\right]$ & \\
\hline
\end{tabular}

Unfortunately, the morphology of Scottish Gaelic provides almost no opportunity to demonstrate the productivity of svarabhakti through alternations. Although a phenomenon of stem-internal /ə/-syncope may feed svarabhakti by bringing together clusters of the appropriate type, I show in $\$ 3.3$ that syncopated stems are synchronically suppletive. Consonantinitial suffixes are rare in Scottish Gaelic, and those that do occur with any degree of productivity all begin with a coronal-meaning that the only logically possible way for suffixation to feed svarabhakti is if one of these suffixes happens to combine with a stem ending in $/ \mathrm{m} /$. Such a combination does not occur in the Lewis data, but Wentworth (2005) records the form cuimte [ $\mathrm{k}^{\mathrm{h}} \mathrm{umu}^{\mathrm{h}} \mathrm{t}^{\mathrm{j}} \mathrm{\partial}$ ] 'well-shaped' for Gairloch, Ross-shire-from the verb cum 'shape' (which he does not record) + the adjectival suffix -te [- ${ }^{\mathrm{h}} \mathrm{t} \mathrm{j}$ ] - in which svarabhakti occurs as predicted. Svarabhakti can also be observed in English loans such as bargan [parákan] 'bargain' or targaid 
[ $\mathrm{t}^{\mathrm{h}}$ arákat'] 'target', but the exact age of these loans is not clear. The claim that svarabhakti is a productive process is therefore based primarily on the predictable quality and regular distribution of svarabhakti vowels. I will assume that all forms with svarabhakti contain an underlying heterorganic RC cluster, e.g. fairrge /fark ${ }^{\mathrm{j}}$ ə/ 'rough sea', dorgh /țory/ 'fishing line', and that svarabhakti occurs in order to break up clusters of this type unless either (i) R is lenis and C is a pre-aspirated stop, or (ii) $R$ is preceeded by a long vowel or diphthong. I will follow several authors in assuming that the svarabhakti vowel acquires its quality through autosegmental feature spreading (Clements 1986; Ní Chiosáin 1994; Halle 1995; Halle et al. 2000), but this aspect of the phenomenon lies outwith the scope of the present paper.

\subsection{Apparent irregularities}

Lewis Gaelic displays a number of apparent exceptions to the rule in (12), most of which fall into two groups. First of all, a set of forms exists in which svarabhakti appears to overapply before hiatus:

$$
\begin{aligned}
& \text { (13) Aonghas [unúres] *[únəs] 'Angus' } \\
& \text { falbhaidh [faLái] *[fáci] 'leave.NPST' } \\
& \text { mailghean [maLáən] *[máLən] 'eyebrow.PL' } \\
& \text { marbhaidh [marái] *[mári] 'kill.NPST' }
\end{aligned}
$$

Recall from §2.2, however, that for independent reasons I consider hiatus to contain an underspecified consonant $\left[\mathrm{X}^{(\mathrm{j})}\right]$ in Scottish Gaelic. Accordingly, I assume that the forms in (13) contain an underlying cluster of a sonorant $+/ \mathrm{X} /$, e.g. Aonghas /XunXəs// 'Angus'. I will regard a cluster as heterorganic whenever both consonants bear non-identical primary place features, including when one of them is unspecified for place (note that svarabhakti can occur before placeless [h], e.g. onfhadh [onóhəy] 'stormy sea'). An underlying cluster of a sonorant $+/ \mathrm{X} /$ is thus heterorganic and is broken up by svarabhakti in the usual manner. Svarabhakti in these forms therefore does not display overapplication at all, but rather reflects covert phonological structure.

Secondly, another set of forms exists in which svarabhakti underapplies before [h]:

$$
\text { ceathrair }\left[\mathrm{k}^{\mathrm{jh}} \text { ćrhər }^{\mathrm{j}}\right] \quad *\left[\mathrm{k}^{\mathrm{jh}} \varepsilon \mathrm{erćh}^{\mathrm{j}}\right] \text { 'four.PERS' }
$$




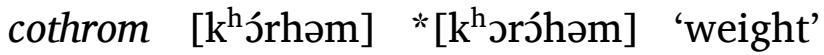

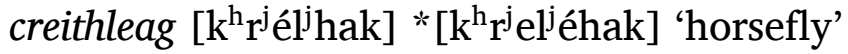

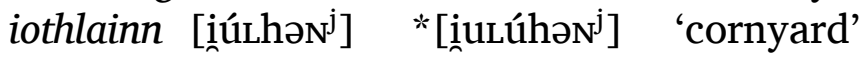

However, there is clear independent evidence for a phrase-level process that metathesises underlying $/ \mathrm{h} /+$ sonorant clusters in Scottish Gaelic. This metathesis can be seen affecting the word-initial clusters $/ \mathrm{t}^{\mathrm{h}} \mathrm{r} S \mathrm{~N} \int \mathrm{N}^{\mathrm{j}} \mathrm{SL}_{\mathrm{L}} \int_{\mathrm{L}}^{\mathrm{j}} \mathrm{SR} /$ when they undergo the lenition mutation in some of the dialects of Skye described by Borgstrøm (1941: 41-42). In the dialects in question, these clusters normally become $\left[\mathrm{hr} h n \mathrm{hn} h \mathrm{hL} \mathrm{l}^{\mathrm{j}} \mathrm{hr}\right]$ respectively under lenition but are metathesised to [rh] etc. when preceded by a vowel. In Lewis, the lenited grades of word-initial $/ \mathrm{s} \sim \int /+$ sonorant clusters do not contain [h], but Oftedal (1956: 162) reports for Leurbost exactly the same alternation between [hr] and [rh] in the lenited grade of $/ \mathrm{t}^{\mathrm{h}} \mathrm{r}$, and this is confirmed by my own observations in Ness. ${ }^{3} \mathrm{I}$ therefore assume that the forms in (14) contain an underlying cluster of $/ \mathrm{h} /+$ sonorant, e.g. ceathrair $/ \mathrm{k}^{\mathrm{jh}}$ ehror $\mathrm{r}^{\mathrm{j}}$ ' 'four.PERS', and that svarabhakti is counterfed by this phrase-level metathesis.

Once these two sets of forms are accounted for, there remain in the Lewis data a small number of forms in which svarabhakti appears to misapply. First of all, for Leurbost Gaelic, Oftedal (1956: 239) notes that a svarabhakti vowel may occur word-finally in two common verbs. These verbs both display final [v] when a vowel-initial word follows, but not elsewhere:

$$
\begin{aligned}
& \text { Before V: Elsewhere: } \\
& \text { falbh [faLáv] [faLá] 'leave' } \\
& \text { marbh [maráv] [mará] 'kill' }
\end{aligned}
$$

Only the forms with [v] occur in Bernera and Ness. I assume that these two verbs underlyingly contain a floating final $/ \mathrm{v} /$ in Leurbost, i.e. /faL(v)/, /mar(v)/, which triggers svarabhakti yet is itself realised only when followed by a vowel-initial word. "Liaison" consonants like this are not unprecedented in Scottish Gaelic and occur frequently in function words, e.g. the 3SG.F possessive particle $a(h-)$ [ə $\sim \partial_{\lrcorner} \mathrm{h}$ ] or the preposition $d o(d h$ ')

\footnotetext{
${ }^{3}$ Borgstrøm (1940: 73) also reports the alternation for Bernera, but says nothing of its conditioning.
} 


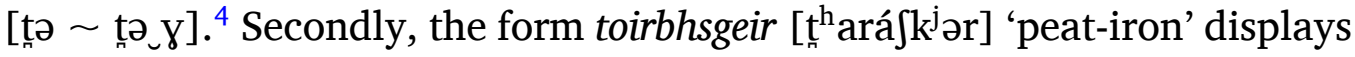
a svarabhakti vowel between two coronal consonants [r] and [S]. This form reflects a borrowing of Old Norse torfskeri, containing the sequence /rvs/ (Oftedal 1956: 55), which leads Smith (1999: 598-599) to propose that /v/ is still present underlyingly in the Scottish Gaelic form, i.e. $/ \mathrm{t}^{\mathrm{h}}$ arv $\int \mathrm{k}^{\mathrm{j}} ə \mathrm{r} /$. Although there is no independent evidence for underlying / $/ \mathrm{v}$ in this particular form, there is certainly evidence for a synchronic process that deletes $/ \mathrm{v} /$ before obstruents at some stage in the phonological derivation, e.g. meanbh [menźv] 'tiny' but meanbh-chuileag ['mené,xul'ak] 'midge' (lit. 'tiny fly'). Finally, the form cainb [k ${ }^{\mathrm{h}}$ anáh $\mathrm{p}$ ] 'hemp', reported by Oftedal (1956) for Leurbost, displays a svarabhakti vowel between a lenis sonorant and a pre-aspirated stop. This is the one form in the Lewis data that we can say with certainty is truly irregular, and we will return to it in §4.4.

\section{$3.3 /$ / /-syncope and svarabhakti}

Svarabhakti interacts in an interesting manner with a phenomenon of stem-internal /ə/-syncope that often affects suffixed forms. In Scottish Gaelic, many stems display an alternation between a disyllabic allomorph with [ə] in the second syllable and a monosyllabic allomorph without. The disyllabic allomorph occurs in unsuffixed forms and the monosyllabic one when a vowel-initial suffix is present:

\begin{tabular}{|c|c|c|}
\hline \multicolumn{3}{|c|}{ NPST bleòghnaidh [pj卢cjkenď̌n-i] } \\
\hline & {$\left[\mathrm{k}^{\mathrm{h}}\right.$ árət $\left.\mathrm{t}^{\mathrm{j}}\right]$ 'friend' } & PL càirdean \\
\hline & 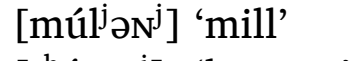 & muilnean \\
\hline tachair & 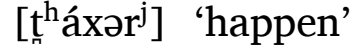 & NPST tachraidh \\
\hline
\end{tabular}

The alternations accompanying /ə/-syncope are often highly complex. Interestingly, [ə] can also alternate with a svarabhakti vowel in exactly those cases where syncope would bring about a cluster of the type targeted by svarabhakti:

(17) aithnich [ánəx ${ }^{\mathrm{j}}$ ' 'know' NPST aithnchidh [anáx ${ }^{\mathrm{j}-\mathrm{i}]}$

\footnotetext{
${ }^{4}$ The absence of [v] in the suffixed forms falbhaidh [faLá-i] 'leave-NPST' and marbhaidh [mará-i] 'kill-NPST', which appear above in (13), must point to a suppletive stem allomorph in final $/ \mathrm{X} /$ rather than final floating $/ \mathrm{v} /$, since there is no general word-level ban

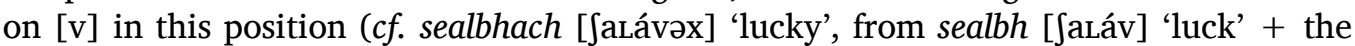
adjectival suffix -(e)ach [-əx]).
} 


\begin{tabular}{|c|c|c|}
\hline balach & [páLəx] ‘boy’ & PL.VOC bhalchaib \\
\hline fairich & [fár'əx ${ }^{\mathrm{j}}$ ] 'feel' & NPST fairchidh \\
\hline fuiling & [fúllijək'] 'suffer' & fuilngidh \\
\hline
\end{tabular}

Although a number of authors treat /ə/-syncope as a synchronically productive process (Bosch 1994; Smith 1999; Hall 2003; Iosad 2015), certain stems do not undergo the process in Lewis Gaelic:

$$
\begin{aligned}
& \text { cuisill } \quad\left[\mathrm{k}^{\mathrm{h}} \mathrm{u} \int \mathrm{\nu}^{\mathrm{j}}\right] \text { 'blood vessel' PL cuisillean } \quad\left[\mathrm{k}^{\mathrm{h}} \mathrm{ú} \int \partial \mathrm{L}^{\mathrm{j}}-\mathrm{j}^{\mathrm{j}}\right]
\end{aligned}
$$

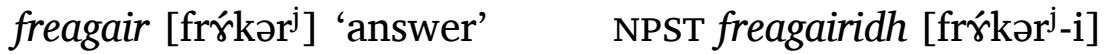

Given the lexically specific nature of the phenomenon, I assume that no synchronic phonological process is involved. Instead, I propose that the forms in (16) and (17) have stems represented lexically by two listed allomorphs, e.g. tachair $/\left\{\mathrm{t}^{\mathrm{h}}\right.$ axər $\left.\mathrm{r}^{\mathrm{j}}, \mathrm{t}^{\mathrm{h}} \operatorname{axr}\right\} /$ 'happen', fairich $/\left\{\mathrm{far}^{\mathrm{j}} \partial \mathrm{x}^{\mathrm{j}}, \mathrm{far}^{\mathrm{j}} \mathrm{x}^{\mathrm{j}}\right\} /$ 'feel', and that the disyllabic allomorph is selected in unsuffixed forms and the monosyllabic allomorph in suffixed forms. If a form such as fairchidh [far'áx ${ }^{j}-\mathrm{i}$ ] 'feel-NPST' is derived from a monosyllabic stem allomorph $/ \operatorname{far}^{\mathrm{j}} \mathrm{x}^{\mathrm{j}}$ /, then svarabhakti is predicted to occur in the usual manner.

\section{Stem-level weight-by-position}

In preparation for a discussion of the derivation of svarabhakti groups, this part of the analysis examines the moraicity of coda consonants at the stem level in Lewis Gaelic. By considering svarabhakti in parallel with a process of lengthening that affects vowels before tautosyllabic fortis sonorants, I offer a unified account in which both processes occur in the wordlevel phonology and make use of morae headed by coda sonorants in the stem-level output. I propose that coda sonorants are subject to weight-byposition (WBP; Hayes 1989) at the stem level under certain circumstances. Although these morae are subsequently transferred onto adjacent vowels at the word level in Lewis Gaelic, I show that the stem-level representations proposed here are directly observable in other dialects in which lengthening and/or svarabhakti do not occur. Only stressed syllables are considered, since lengthening and svarabhakti do not affect unstressed syllables. $\S 4.1$ considers stem-final sonorants, $\$ 4.2$ considers stem-internal sonorants before pre-aspirated stops, and $\$ 4.3$ considers stem-internal sonorants before other consonant types. $\$ 4.4$ provides a summary, and shows how the 
system of stem-level WBP proposed here correctly predicts a particular case of underapplication of svarabhakti in certain non-Lewis dialects, as well as the existence of exceptional items like cainb [ $\mathrm{k}^{\mathrm{h}}$ anáh $\mathrm{p}$ ] 'hemp' in Lewis.

\subsection{Stem-final sonorants}

In Lewis Gaelic, monosyllabic stems ending in fortis sonorants display alternations whereby the sonorant is preceded by a long vowel or diphthong when in the coda, and by a short vowel when resyllabified into the onset:

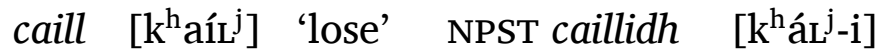

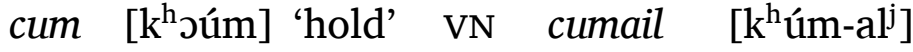

$$
\begin{aligned}
& \text { geàrr [kjă:R] 'cut' VN gearradh [kंáR-əу] }
\end{aligned}
$$

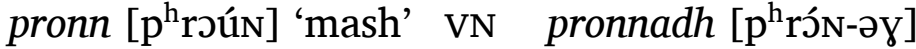

Diphthongs ending in $[\mathrm{u}]$ occur before [N L], diphthongs ending in [i] before $\left[\mathrm{N}^{\mathrm{j}} \mathrm{L}^{\mathrm{j}}\right]$, and long monophthongs before $[\mathrm{R}]$; all three may occur before [m] depending on circumstances that need not be discussed here. Forms

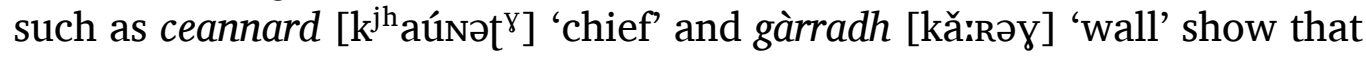
there is no general shortening process in this position, and note also the direction of neutralisation of the vowels in cum and pronn. I therefore assume that these forms contain a short vowel underlyingly, e.g. caill $/ \mathrm{k}^{\mathrm{h}} \mathrm{aL}^{\mathrm{j}} /$ 'lose', and that a word-level phonological process triggers lengthening or diphthongisation of an underlying short vowel before a tautosyllabic fortis sonorant. For simplicity I will refer to this process as lengthening, since the qualitative distinction between long vowels and diphthongs is not relevant to us here.

Lengthening displays underapplication under certain circumstances. First of all, recall from $\S 1.2$ that word-level fortition processes convert certain underlyingly lenis coronal sonorants into fortis ones. These processes fail to feed lengthening:

a. Underlyingly lenis $\left[\mathrm{N}^{\mathrm{j}}\right]$ :

buin [púNợ] *[pəíNj] 'base.GEN' (NOM bun [pún]])

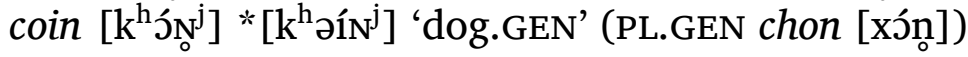

b. Underlyingly lenis [L]:

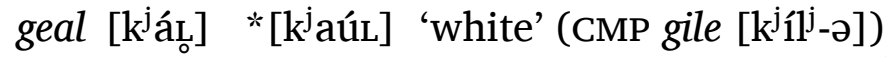
mol [mós] *[məúL] 'shingle' (GEN muile [múlij-ə]) 
Additionally, another word-level fortition process converts lenis /n/ into fortis $[\mathrm{N}]$ before a coronal stop. This process also fails to feed lengthening:

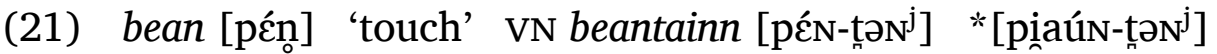

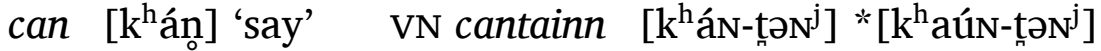

Here we seem to have what is effectively a chain shift in the word-level phonology: various fortition processes trigger $\left[\mathrm{Vn}^{(\mathrm{j})} \mathrm{Vl}\right] \rightarrow\left[\mathrm{VN}^{(\mathrm{j})} \mathrm{VL}_{\mathrm{L}}\right]$ while

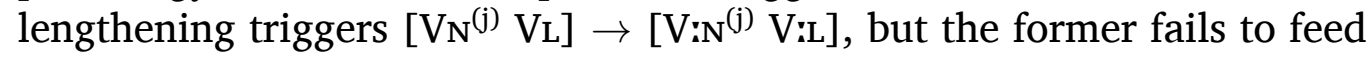
the latter. At first glance, this is highly problematic for an Optimality Theoretic analysis. Simply being fortis is not enough to guarantee that a stem-final coda sonorant triggers lengthening in the word-level output: apparently, lengthening may only occur if the sonorant was already fortis in the word-level input. The simplest solution to this paradoxassuming only traditional Optimality Theoretic markedness and faithfulness constraints-is to propose that there is in fact no chain shift at all, and that stem-final fortis coda sonorants exit the stem-level phonology bearing some additional marking besides whatever featural properties are responsible for the fortis-lenis contrast in general. Evidence from other dialects of Scottish Gaelic suggests that this additional marking is a mora.

In parts of Argyll, such as Islay (Grannd 1985; 2000) and Jura (Jones 2000; 2006; 2010), lengthening does not occur before stem-final fortis coda nasals and laterals (for simplicity, historically fortis rhotics-which do trigger lengthening - will be set aside here). Instead, they are geminated when (underlyingly) fortis but not when lenis (all Islay forms in this section are from SGDS):

$$
\text { Lewis Islay }
$$

a. Fortis nasal or lateral:

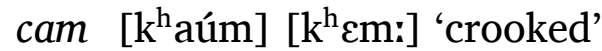

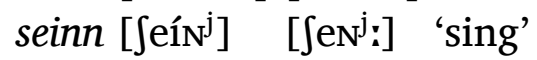

toll [ $\mathrm{t}^{\mathrm{h}} \partial$ úL $]$ [ $\mathrm{t}^{\mathrm{h}} \mathrm{OL:}$ : 'hole'

tuill [ $\left.\mathrm{t}^{\mathrm{h}} \partial^{\prime} \mathrm{L}^{\mathrm{j}}\right] \quad\left[\mathrm{t}^{\mathrm{h}} \mathrm{uL} \mathrm{L}^{\mathrm{j}} \mathrm{:}\right]$ 'hole.GEN'

b. Lenis nasal or lateral:

bean [péñ] [pen] 'wife'

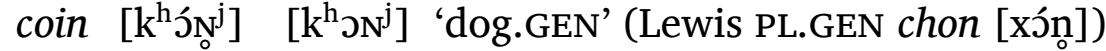

fuil [fúljo [fulj] 'blood'

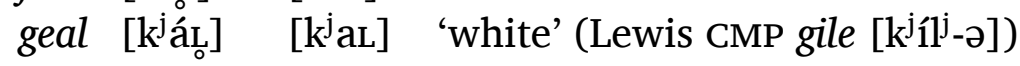


Islay Gaelic therefore displays an overtly moraic sonorant wherever Lewis displays lengthening of the preceding vowel. I propose that-ignoring occasional differences in segmental quality - the Lewis stem-level outputs for the forms in (22a) are in fact identical to the Islay surface forms: specifically, stem-final fortis sonorants are subject to WBP in the stemlevel phonology, thus rendering them moraic, while lenis ones are not. The crucial difference between the two dialects is that Lewis Gaelic has a word-level phonological process that subsequently transfers a mora from a moraic coda sonorant onto a preceding tautosyllabic vowel, triggering lengthening, while Islay Gaelic does not. I assume that if the sonorant is resyllabified into an onset at the word level, as occurs before a vowelinitial suffix, then this mora is lost. This approach allows us to account for the lengthening alternations in (19) as well as the paradoxical underapplication of lengthening in (20) and (21), while simultaneously reducing the difference between the Lewis and Islay forms in (22a) to the presence of a word-level mora-transfer process in the former dialect but not the latter. Note that what I propose here is effectively a stratal version of Ní Chiosáin's (1991) analysis of the cognate phenomenon in Irish. The qualitative fortis-lenis distinction has been lost in the Irish variety in question, but historically fortis stem-final sonorants trigger lengthening alternations similar to those in (19). Ní Chiosáin analyses these sonorants as lexically moraic, and this mora is either transferred or lost just as I claim occurs at the word level in Lewis Gaelic.

When a stem-final fortis sonorant is preceded by an underlying long vowel or diphthong, no lengthening occurs in Lewis and no gemination occurs in Islay. In the following forms, the quality of the preceding long vowel or diphthong indicates that it is not the product of lengthening:

$$
\begin{aligned}
& \text { Lewis Islay } \\
& \text { màm [mă:m] [me:m] 'lump' }
\end{aligned}
$$

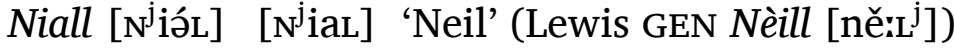

Since Islay Gaelic realises moraic coda consonants as geminates, the final sonorant in these Islay forms cannot be moraic. I therefore assume that stem-level WBP is blocked when the preceding vowel is dimoraic, which can be accounted for by common constraints against superheavy syllables. We can therefore now make the following generalisation about stem-final sonorants: 
(24) When stem-final, fortis coda sonorants (but not lenis ones) are subject to WBP at the stem-level, unless this would result in a superheavy syllable.

In the following sections, we will build upon this generalisation in order to include stem-internal coda sonorants.

\subsection{Stem-internal sonorants before pre-aspirated stops}

When followed by a pre-aspirated stop, stem-internal fortis and lenis sonorants behave in different ways in Lewis Gaelic. If the cluster is homorganic, various phonotactic restrictions mean that it is possible to independently distinguish between underlyingly fortis and lenis sonorants only in the case of the laterals. The effects of lengthening can be observed before fortis laterals, while lenis laterals may freely be preceded by a short vowel (recall that pre-aspiration of stops is realised as devoicing of any preceding sonorant):

a. Fortis lateral + homorganic pre-aspirated stop:

allt [aúLtot] 'stream' uillt $\left[\right.$ วít $\left._{0}^{\mathrm{j}} \mathrm{t}^{\mathrm{j}}\right]$ 'stream.GEN'

b. Lenis lateral + homorganic pre-aspirated stop: alt [ádt] 'joint' uilt [úl $\left.{ }_{0}^{\mathrm{j}} \mathrm{j}\right]$ 'joint.GEN'

Meanwhile, if the cluster is heterorganic, recall from $\S 3.1$ that svarabhakti occurs if the sonorant is fortis but not if it is lenis:

a. Fortis sonorant + heterorganic pre-aspirated stop:

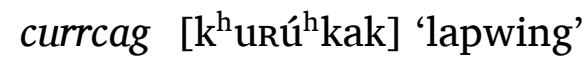

b. Lenis sonorant + heterorganic pre-aspirated stop:

\begin{tabular}{|c|c|c|}
\hline cearc & [k $\left.{ }^{\mathrm{jh}} \mathrm{\varepsilon} \hat{\mathrm{r}} \mathrm{rk}\right]$ & ‘hen’ \\
\hline corp & [khórp] & 'body' \\
\hline $\begin{array}{l}\text { olc } \\
\text { peirceall }\end{array}$ & $\begin{array}{l}{[\text { [ólk] }} \\
{\left[p^{\mathrm{h}} \mathrm{é}^{\mathrm{j}} \mathrm{k}^{\mathrm{j}}{ }^{2} \mathrm{~L}\right]}\end{array}$ & $\begin{array}{l}\left.\text { 'evil' (GEN uilc [úl } \mathrm{l}_{\mathrm{j}}^{\mathrm{j}} \mathrm{k}^{\mathrm{j}}\right] \text { ) } \\
\text { 'jaw' }\end{array}$ \\
\hline
\end{tabular}

These forms reveal an important parallel between lengthening and svarabhakti. Both processes occur before a pre-aspirated stop only if the sonorant is fortis, with the choice between the two determined by whether the 
cluster is homorganic or heterorganic. This complementary relationship suggests that a similar mechanism lies behind both processes, allowing us to generalise the mora-transfer analysis from lengthening to svarabhakti. In order to provide a maximally simple and unified account of the two processes, I therefore propose that svarabhakti represents a word-level mora transfer process just like lengthening, and thus may only occur if the sonorant is moraic in the stem-level output. Since I have assumed that a constraint against superheavy syllables blocks WBP when the preceding vowel is dimoraic, this approach also captures the fact that svarabhakti never occurs after a long vowel or diphthong. Note that this analysis is again similar to that proposed for the cognate phenomenon in Irish by Ní Chiosáin (1991), who also recognises a link between svarabhakti and lengthening (see also Ó Baoill 1980, who discusses this link from a diachronic perspective). According to her rule-based analysis, sonorants are subject to WBP under certain conditions, and this mora is subsequently transferred to a svarabhakti vowel. Similarly, Hall's (2003) analysis also considers svarabhakti to be dependent upon the moraicity of a coda sonorant. We can therefore now amend the generalisation in (24) as follows, in order to include stem-internal sonorants before pre-aspirated stops:

(27) When stem-final or followed by a pre-aspirated stop, fortis coda sonorants (but not lenis ones) are subject to WBP at the stem-level, unless this would result in a superheavy syllable.

We will further build upon this generalisation in the following section, in order to include stem-internal coda sonorants before other consonant types.

\subsection{Stem-internal sonorants before other consonant types}

When the following consonant is not a pre-aspirated stop, it is not necessary to make a distinction between stem-internal fortis and lenis sonorants in Lewis Gaelic. If the cluster is homorganic, only fortis sonorants are found, and the effects of lengthening can again be observed (note that a velarised retroflex consonant is the regular outcome of $/ \mathrm{R} /+$ coronal):

(28) Fortis sonorant + homorganic consonant: 


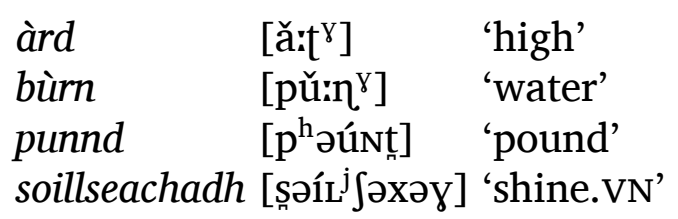

Meanwhile, if the cluster is heterorganic, recall from $\S 3.1$ that svarabhakti occurs regardless of whether the sonorant is fortis or lenis:

a. Fortis sonorant + heterorganic consonant:

crannchar [ $\mathrm{k}^{\mathrm{h}}$ ranáxər] 'fate'

fairrge [faRákjə] 'rough sea'

imleag [imíl $\left.{ }^{\mathrm{j} a k}\right]$ 'navel'

b. Lenis sonorant + heterorganic consonant:

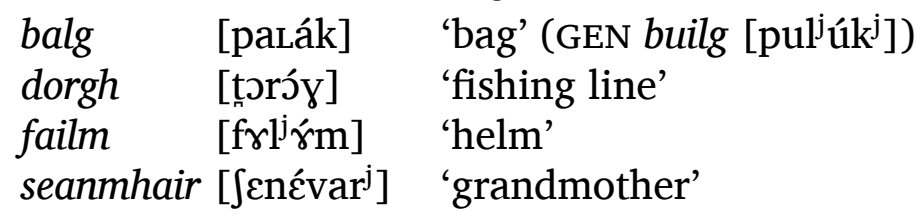

A maximally simple and unified account of lengthening and svarabhakti therefore requires that all stem-internal coda sonorants-not just fortis ones-are subject to stem-level WBP when followed by a consonant that is not a pre-aspirated stop (unless this would result in a superheavy syllable). We can therefore amend the generalisation in (27) as follows, in order to include stem-internal sonorants before other consonant types:

a. When stem-final or followed by a pre-aspirated stop, fortis coda sonorants (but not lenis ones) are subject to WBP at the stem-level;

b. When followed by a consonant that is not a pre-aspirated stop, all coda sonorants are subject to WBP at the stem-level;

Unless, in either case, this would result in a superheavy syllable.

This generalisation now covers all coda sonorants in Lewis Gaelic. ${ }^{5}$ We therefore have the following stem-level outputs for forms such as those in (12):

\footnotetext{
${ }^{5}$ The somewhat marginal cluster [ $\left.\mathrm{nk}\right]$ is exceptional in that it may freely be preceded by a short vowel, e.g. Frangach [frańkəx] 'French', in spite of the fact that the nasal should be moraic in the stem-level output according to (30). Given the position of the pitch peak, which is based on my own impression of the pronunciation of forms of this type in Ness, I assume that the nasal is indeed subject to stem-level WBP as expected, but that wordlevel mora transfer simply does not affect [ $\mathrm{\eta}]$. The nasal therefore remains moraic on the
} 
(31) If

a. $\mathrm{R}$ is preceded by a short vowel, and

i. $\quad \mathrm{R}$ is fortis $\rightarrow \mathrm{R}$ is moraic:

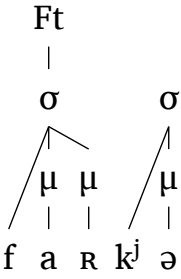

ii. $\mathrm{R}$ is lenis, and

A. C is a pre-aspirated stop $\rightarrow \mathrm{R}$ is not moraic:

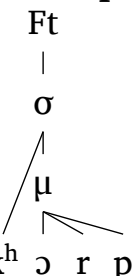

B. C is not a pre-aspirated stop $\rightarrow \mathrm{R}$ is moraic:

$\mathrm{Ft}$

।

$\sigma$



$\mu \mu$

$1 \mathrm{~N}$

$\begin{array}{llll}t & \mathrm{r} & \mathrm{r} & \mathrm{r}\end{array}$

b. $\mathrm{R}$ is preceded by a long vowel or diphthong $\rightarrow \mathrm{R}$ is not moraic:

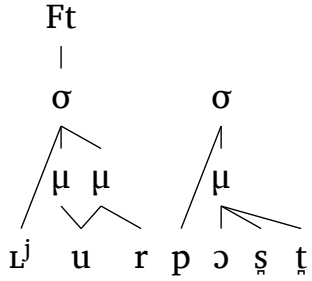

In $\S 5$ it will be shown how the observed surface forms are derived from these stem-level outputs.

Importantly, this analysis leads us to expect that any dialect lacking svarabhakti will display a moraic coda sonorant on the surface wherever

surface, and accordingly bears the second-mora pitch peak of C2. The analysis of forms like this as containing a dimoraic syllable, despite the vowel being short, is supported by the fact that under slenderisation they alternate with forms that contain a diphthong and are thus clearly dimoraic, e.g. Fraing [fraín ${ }^{\mathrm{j}} \mathrm{k}^{\mathrm{j}}$ ] 'France'. 
svarabhakti occurs in Lewis Gaelic. It will therefore now be useful to look at the dialect of East Perthshire described by Ó Murchú (1989), in which svarabhakti does not occur. This dialect differs from that of Lewis in several important ways. First of all, the qualitative fortis-lenis distinction has been lost in East Perthshire, but historically fortis stem-final nasals and laterals are realised as geminates-i.e. they are overtly moraic-when in coda position while historically lenis ones are not (again for simplicity, historically fortis rhotics will be set aside here):

$$
\text { Lewis E. Perths. }
$$

a. Fortis nasal or lateral:

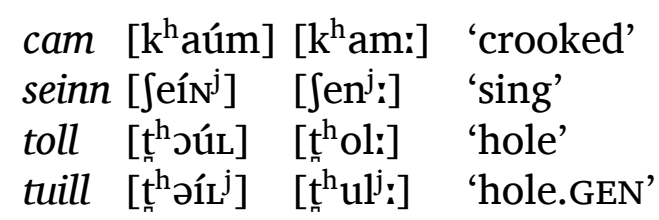

b. Lenis nasal or lateral:

\begin{tabular}{|c|c|c|}
\hline bean [péno] & [pen] & ‘wife’ \\
\hline $\operatorname{coin}\left[\mathrm{k}^{\mathrm{h}} \mathrm{jos}_{\mathrm{o}}^{\mathrm{j}}\right]$ & {$\left[\mathrm{k}^{\mathrm{h}} \mathrm{\jmath} \mathrm{n}^{\mathrm{j}}\right]$} & ‘dog.GEN’ (Lewis PL.GEN chon [xóno]) \\
\hline [fúl $\left.\mathrm{o}^{\mathrm{j}}\right]$ & {$\left[\mathrm{ful}^{\mathrm{j}}\right]$} & 'blood' \\
\hline [kjáç] & {$\left[\mathrm{k}^{\mathrm{j}} \mathrm{al}\right]$} & ‘white’ (Lewis CMP gile [ $\left[\mathrm{k}^{\mathrm{j}} \mathrm{l}^{\prime} \mathrm{l}^{\mathrm{j}}-ə\right]$ ) \\
\hline
\end{tabular}

The fact that East Perthshire Gaelic has preserved the historical fortislenis contrast stem-finally by means of lexically contrastive moraicity suggests an earlier diachronic stage at which stem-final fortis coda sonorants were obligatorily moraic while lenis ones were not, just as is observed on the surface in present-day Islay Gaelic and just as I propose in (30) for the stem-level output in Lewis. Secondly, pre-aspiration has been lost in East Perthshire, but the historical contrast between plain and pre-aspirated stops is reflected in the moraicity of a preceding historically lenis sonorant. Historically pre-aspirated stops are preceded by singleton sonorants, and historically plain stops by geminate sonorants (where Lewis Gaelic displays svarabhakti):

$$
\text { Lewis E. Perths. }
$$

a. Lenis sonorant + pre-aspirated stop:

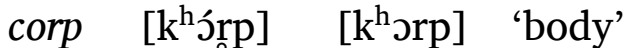

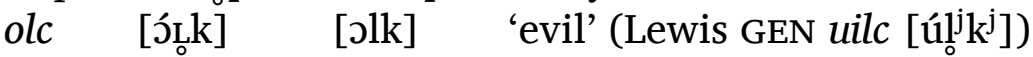

b. Lenis sonorant + plain stop: 


\section{balg [paLák] [pal:k] 'bag' (Lewis GEN builg [puljúkij]) earball [urúupəu] [iar:pəl] 'tail'}

This suggests an earlier diachronic stage at which lenis coda sonorants were obligatorily moraic before plain stops but not before pre-aspirated stops, which is again in accordance with what I propose in (30) for the stem-level output in Lewis. Finally, historically lenis stops are always geminate before other consonant types (where Lewis displays svarabhakti):

$$
\begin{aligned}
& \text { Lenis sonorant }+ \text { consonant: } \\
& \text { Lewis E. Perths. } \\
& \text { ainm [anám] [عn:m] 'name' } \\
& \text { dorcha [toróx] [tor:x] 'dark' }
\end{aligned}
$$

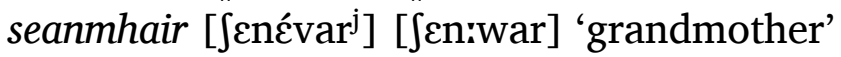

$$
\begin{aligned}
& \text { suirghe [șur }{ }^{\mathrm{j}} \text { új] [sur:j] 'court.vN' }
\end{aligned}
$$

Lenis coda sonorants are therefore obligatorily moraic before other consonant types, which yet again agrees with what I propose in (30) for the stemlevel output in Lewis. The moraicity of coda sonorants in East Perthshire Gaelic thus exactly matches what I propose for the stem-level output in Lewis in every single case. ${ }^{6}$

\subsection{Summary}

To summarise, I have argued that stem-level WBP in Lewis Gaelic affects coda sonorants according to the generalisation in (30). Certain aspects of this system are typologically unsurprising. Sonorants are the only consonants that show any evidence of being moraic at the stem level in Lewis

\footnotetext{
${ }^{6}$ It is possible that the absence of svarabhakti in East Perthshire may in fact represent an innovation, rather the preservation of a pre-svarabhakti stage in the development of Scottish Gaelic. Under this scenario, the svarabhakti vowel probably would have undergone reduction to [ə] just as in other eastern dialects such as East Sutherland (Dorian 1978), Northeast Ross-shire (Watson 1974) and Aberdeenshire (Watson \& Clement 1981), followed by eventual loss. However, it is unclear why this deletion would have affected svarabhakti vowels without also affecting ordinary unstressed [ə] in similar positions (e.g. biorach [pirəx] 'pointed', not *[pir:x], corresponding to Lewis [pírəx])—especially since, in those dialects where svarabhakti vowels are prosodically distinct from ordinary unstressed vowels, it is always svarabhakti vowels that have greater prominence in terms of pitch and/or duration (see §6.1).
} 
Gaelic, which is consistent with the fact that WBP tends to target coda consonants that exceed a language-specific threshold of sonority (Zec 1995; Morén 1999). I assume that the blocking of WBP on a stem-final lenis coda sonorant is due to a constraint against moraic consonants in final position, while the blocking of WBP on a lenis coda sonorant followed by a pre-aspirated stop is due to a constraint against moraicity on voiceless consonants (which have relatively low sonority)—recall that pre-aspiration is here realised as devoicing of the sonorant. Although the featural content of the fortis-lenis contrast is unclear, I assume that these blocking processes are overridden by a stem-level requirement for fortis sonorants to project a mora wherever possible. Coupled with an undominated constraint against superheavy syllables, this brings about the observed system.

By ascribing the blocking of svarabhakti between a lenis sonorant and a pre-aspirated stop to the absence of an available mora in the stem-level output, the present analysis correctly predicts the behaviour of a particular set of forms that display underapplication of svarabhakti in a number of non-Lewis dialects. Where Lewis Gaelic has a contrast between preaspirated $\left[{ }^{\mathrm{h}} \mathrm{k}\right]$ and a cluster [xk], dialects such as that of Barra instead merge both to [xk] (Borgstrøm 1937; 1940):
Lewis Barra
a. $\left[{ }^{\mathrm{h}} \mathrm{k}\right]$ in Lewis $\sim[\mathrm{xk}]$ in Barra:

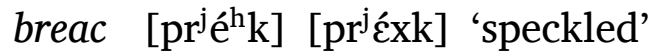
cnoc [ $\left.\mathrm{k}^{\mathrm{h}} \mathrm{r} \mathfrak{s}^{\mathrm{h}} \mathrm{k}\right]\left[\mathrm{k}^{\mathrm{h}} \mathrm{róxk}\right]$ 'hill'
b. [xk] in both Lewis and Barra:

\begin{tabular}{|c|c|}
\hline bochd [póxk & [póxk] \\
\hline
\end{tabular}

In Lewis, stem-final $\left[{ }^{\mathrm{h}} \mathrm{k}\right]$ can undergo slenderisation but $[\mathrm{xk}]$ is immune to the process (Borgstrøm 1940: 84; Oftedal 1956: 172). Meanwhile, in Barra, [xk] may undergo slenderisation only when it corresponds to Lewis [ ${ }^{\mathrm{h}} \mathrm{k}$ ], and not when it corresponds to Lewis [xk] (Borgstrøm 1940: 175), e.g. Barra bhric [vríín $\mathrm{x}^{\mathrm{j}} \mathrm{k}^{\mathrm{j}}$ ] 'speckled.M.GEN' but bhochd [vóxk] 'poor.M.GEN'. Since the distinction is evidently visible to inflectional processes, I assume that $/{ }^{\mathrm{h}} \mathrm{k} /$ and $/ \mathrm{xk} /$ both exist underlyingly in Barra and remain distinct until the word-level phonology. The present analysis correctly predicts that svarabhakti will underapply in Barra when a lenis sonorant is followed by an instance of $[\mathrm{xk}]$ that may undergo slenderisation: 


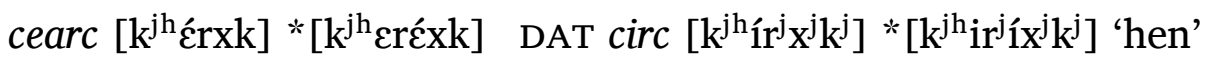

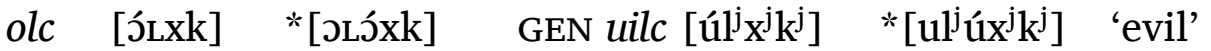

This is because a lenis coda sonorant is not subject to stem-level WBP when followed by an underlying pre-aspirated stop such as ${ }^{\mathrm{h}} \mathrm{k} /$. Since the sonorant is not moraic in the word-level input, svarabhakti is blocked, even though word-level insertion of $\left[\mathrm{x}^{(\mathrm{j})}\right]$ after the sonorant brings about the surface conditions under which svarabhakti is normally observed. A stratal analysis such as this, in which both svarabhakti and lengthening are word-level processes that make use of morae projected by stem-level coda sonorants under certain conditions, is therefore able to account for instances of opacity not only in Lewis Gaelic but in other dialects of Scottish Gaelic as well.

Since the stem-level phonology assigns morae to coda sonorants under well-defined circumstances, the present analysis offers no means by which a sonorant could possibly fail to be moraic in the stem-level output if it meets the conditions for stem-level WBP. This leads to the prediction that all cases of underapplication of lengthening or svarabhakti in Lewis Gaelic can be ascribed to the counterfeeding effects of independently motivated post-stem-level processes. Sure enough, the underapplication of lengthening before derived fortis sonorants in (20) and (21) can be ascribed to word-level fortition processes, while the underapplication of svarabhakti in sonorant $+[\mathrm{h}]$ clusters in (14) can be ascribed to a phrase-level process of metathesis. However, this analysis does not exclude the possibility that coda sonorants may be exceptionally moraic under certain circumstances. If the faithfulness constraints protecting underlyingly moraic coda sonorants are ranked sufficiently high in the stem-level phonology, then a sonorant might be moraic in the stem-level output despite not fulfilling the conditions for stem-level WBP. The form cainb $\left[\mathrm{k}^{\mathrm{h}}\right.$ anáh $\mathrm{p}$ ] 'hemp', mentioned in §3.2, is an example of exactly the type of exception that would be predicted to occur. Although a lenis sonorant does not automatically become moraic at the stem level when followed by a pre-aspirated stop, it can be assumed that $/ \mathrm{n} /$ in this form is underlyingly moraic and that the relevant markedness and faithfulness constraints are ranked in such a way as to ensure that it remains moraic in the stem-level output. This allows svarabhakti to occur at the word level in this form. The present analysis is therefore able to account for exactly the type of misapplica- 
tion of svarabhakti that occurs in the Lewis data, while simultaneously disallowing phenomena that are never observed to occur.

\section{The derivation of svarabhakti groups}

This part of the analysis offers an Optimality Theoretic account of the derivation of svarabhakti groups in the word-level phonology of Lewis Gaelic, showing how the surface structures established in $\S 2$ for svarabhakti forms are derived from the stem-level outputs proposed in §4. §5.1 discusses forms in which svarabhakti occurs in order to break up a heterorganic cluster and $\S 5.2$ discusses cases in which it is blocked. $\S 5.3$ discusses cases involving the interaction of svarabhakti with / $/$ /-syncope.

\subsection{Occurrence of svarabhakti}

According to the analysis so far, a svarabhakti form such as fairrge [faRákj ${ }^{j}$ ] 'rough sea' or dorgh [țoróy] 'fishing line', underlyingly /faRk ${ }^{j} ə /$ and/țory/ respectively, has the stem-level output shown in (31) and a surface form similar to that of balg [pacák] 'bag' in (11). It was proposed in $\S 4$ that svarabhakti is a word-level process that transfers a mora from a coda sonorant onto an epenthetic vowel. Taking dorgh as an example, such a form therefore has the following word-level input and output:

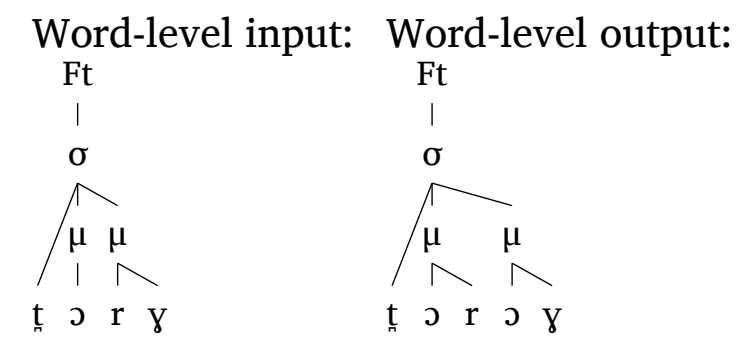

The input syllable count is preserved when svarabhakti occurs, so that the entire svarabhakti group remains monosyllabic. This is in spite of the fact that it is generally assumed that faithfulness constraints cannot directly refer to input syllable structure (e.g. McCarthy 2002: 73-74). In order to account for this, I borrow insights from Köhnlein (2016; 2018), who proposes that the foot head is located at the highest level of metrical representation at which the foot displays binarity: in a foot containing two 
syllables (a syllabic trochee) the head is the first syllable, while in a foot containing one dimoraic syllable (a moraic trochee) the head is the first mora. The foot head is underlined here and in the tableaux below-this is purely illustrative, since the head status of a metrical node follows directly from the tree structure:

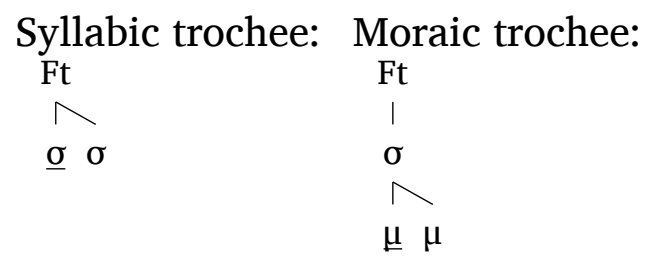

Secondly, I follow Köhnlein (2011; 2016; 2018; see also McCarthy 1995; 2000 ) in claiming that metrical heads are subject to faithfulness. I therefore define a constraint HEADMATCH(Ft) as follows, adapted from Köhnlein (2011: 187; 2016: 98; 2018: 630):

(39) HeAdMAtch(Ft): Let $\mathrm{Ft}_{\mathrm{I}}$ be a foot in the input and let $\mathrm{Ft}_{\mathrm{O}}$ be its output correspondent. Assign a violation mark if the head of $\mathrm{Ft}_{\mathrm{O}}$ is not the output correspondent of the head of $\mathrm{Ft}_{\mathrm{I}}$.

When highly ranked, this constraint can drive faithfulness to input syllable count by ensuring that a monosyllabic foot does not become disyllabic and vice versa.

This part of the analysis also assumes the following constraints, all of which are common in the phonological literature:

(40) AGREE(C-pl): Let $\mathrm{C}_{1} \mathrm{C}_{2}$ be a sequence of two adjacent consonants in the output. Assign a violation mark if there is a C-place feature that is linked to either $\mathrm{C}_{1}$ or $\mathrm{C}_{2}$ but not both.

(41) $\operatorname{DEP}(\mu)$ : Let $\mu$ be a mora in the output. Assign a violation mark if $\mu$ does not have an input correspondent.

(42) DEP(S): Let $S$ be a segment in the output. Assign a violation mark if $S$ does not have an input correspondent.

(43) SONSEQ: Let $\sigma$ be a syllable in the output. Assign a violation mark if $\sigma$ contains more than one sonority peak.

Since svarabhakti targets heterorganic clusters, I assume that it is driven by AgREE(C-pl). If we rank AgREE(C-pl) above DeP(S), and AgREE(C-pl), 
HeAdMATCh(Ft) and DeP( $\mu$ ) above SonSEQ, as in (44), then we obtain the observed result for the word-level input established in (31) for dorgh [țrós] 'fishing line', as shown in the tableau in (45). The fully faithful candidate violates highly-ranked AGREE(C-pl) due to the presence of a heterorganic cluster, forcing epenthesis to occur in violation of DEP(S). ${ }^{7}$ If the svarabhakti vowel were to project a syllable of its own then this would incur a violation of highly-ranked $\operatorname{HEADMATCH}(\mathrm{Ft})$, so the entire svarabhakti group remains monosyllabic in violation of SONSEQ. An alternative repair, in which the svarabhakti vowel projects a new syllable but the first syllable remains dimoraic, is blocked by highly-ranked $\operatorname{DEP}(\mu)$ because it requires the insertion of a mora.

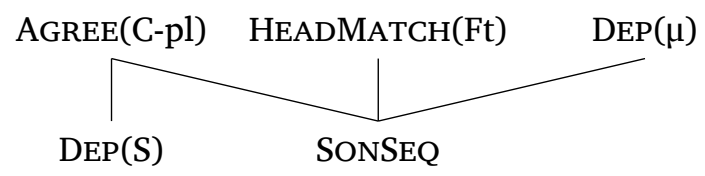

\subsection{Blocking of svarabhakti}

Recall from $\S 3.1$ that svarabhakti fails to occur in a heterorganic RC cluster under two conditions: (i) R is lenis and $\mathrm{C}$ is a pre-aspirated stop; or (ii) $\mathrm{R}$ is preceded by a long vowel or a diphthong. In $\S 4$ I proposed that this is because a coda sonorant is not subject to stem-level WBP in either of those positions. The coda sonorant in forms such as corp [ $\mathrm{k}^{\mathrm{h}}$ órp] 'body' and Liùrbost [L $\mathrm{L}^{\mathrm{j}} \mathrm{urpost}$ ] 'Leurbost', underlyingly $/ \mathrm{k}^{\mathrm{h}} \partial \mathrm{r}^{\mathrm{h}} \mathrm{p} /$ and $/ \mathrm{L}^{\mathrm{j}} \mathrm{u}_{\mu \mu} \mathrm{rpost} /$ respectively, is therefore non-moraic in the word-level input, and the form is unchanged in the word-level output.

I assume that $\operatorname{DEP}(\mu)$ is responsible for the blocking of svarabhakti in forms in which $\mathrm{R}$ is lenis and $\mathrm{C}$ is a pre-aspirated stop. If we further specify the partial word-level ranking in (44) by ranking $\operatorname{DEP}(\mu)$ above AGREE(C-pl), as in (46), then we obtain the observed result for the wordlevel input established in (31) for corp [ $\mathrm{k}^{\mathrm{h}}$ '́rp] 'body', as shown in the tableau in (47). Although the fully faithful candidate violates AGREE(C-pl),

\footnotetext{
${ }^{7}$ For reasons of space I will not consider candidates in which the cluster is repaired by other means, such as deletion or place assimilation.
} 


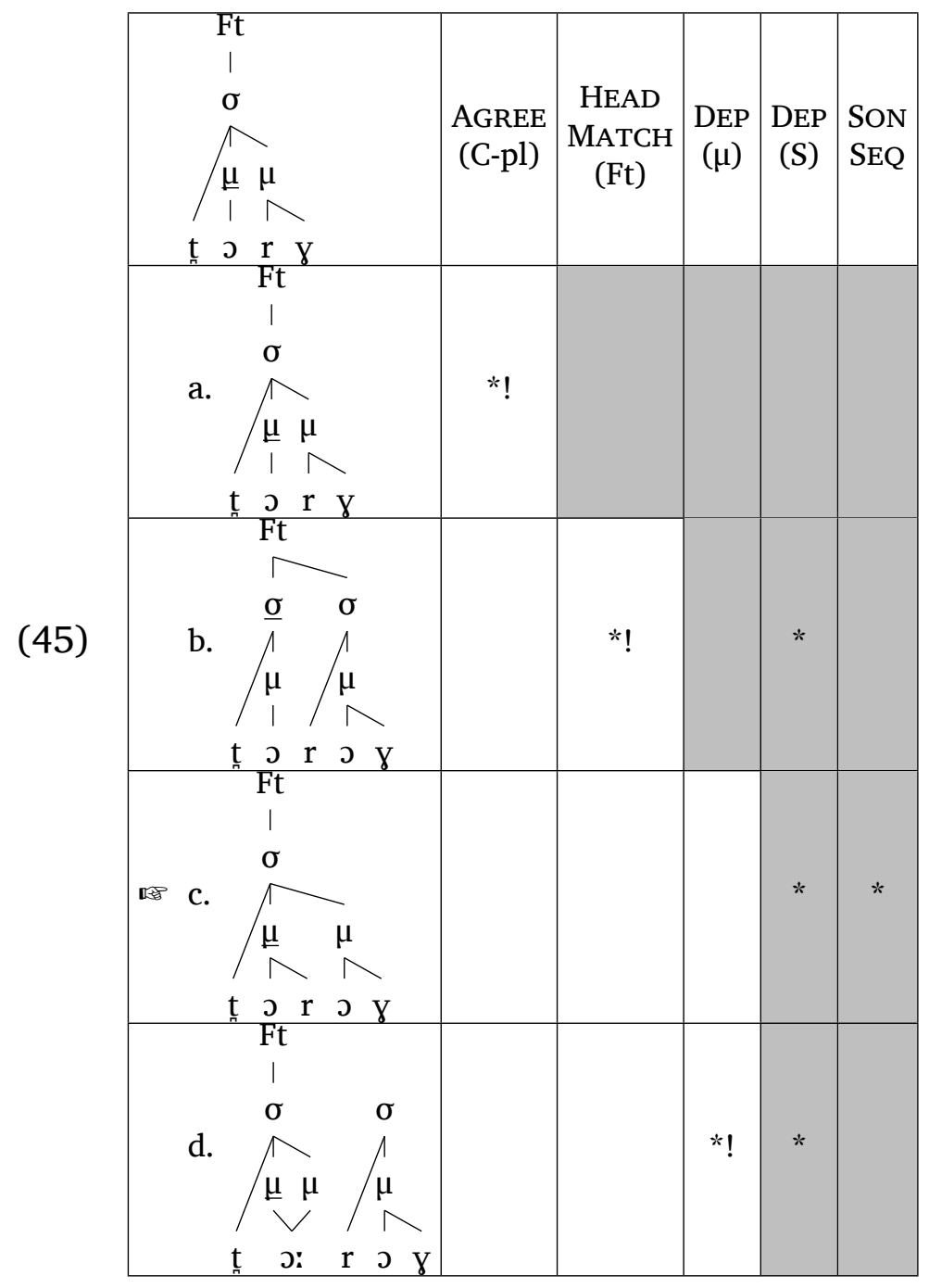

any candidate in which epenthesis occurs must necessarily violate higherranked $\operatorname{DEP}(\mu)$ by inserting a mora. ${ }^{8}$

For the analysis of forms in which $\mathrm{R}$ is preceded by a long vowel or a diphthong, I assume the following additional constraint taken from a

\footnotetext{
${ }^{8}$ It is not immediately obvious where the head occurs in a foot that does not branch at any level of metrical structure, i.e. a monomoraic foot. For the purposes of the tableau in (47) I assume that the head of a monomoraic foot is the syllable. This choice has no bearing on the outcome.
} 
(46)

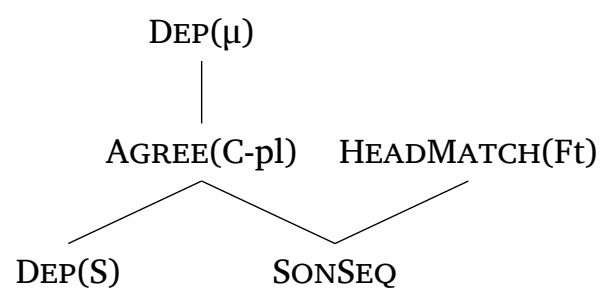

(47)

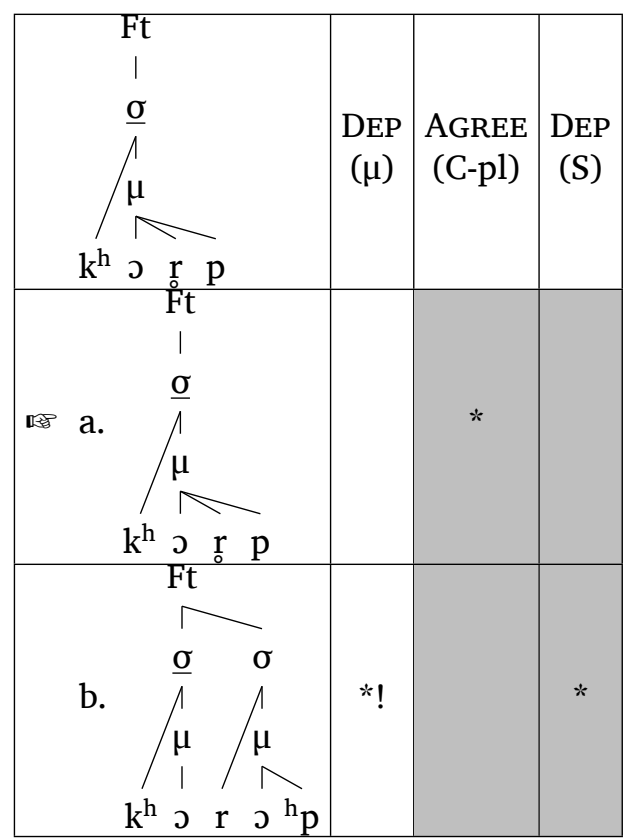

constraint family proposed by Morén (1999):

(48) $\operatorname{MAXLINK}(\mu / \mathrm{V})$ : Let $\mathrm{V}_{\mathrm{I}}$ be a vowel in the input and let $\mathrm{V}_{\mathrm{O}}$ be its output correspondent. Assign a violation mark if $\mathrm{V}_{\mathrm{O}}$ is linked to fewer morae than $\mathrm{V}_{\mathrm{I}}$.

I assume that $\operatorname{DEP}(\mu)$ is once again responsible for the blocking of svarabhakti in forms of this type. If we add to the partial word-level ranking in (46) by ranking MAXLINK( $\mu / \mathrm{V})$ above AGREE(C-pl), as in (49), then we obtain the observed result for the word-level input established in (31) for

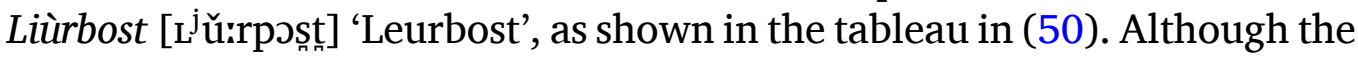
fully faithful candidate again violates AGREE(C-pl), any candidate in which epenthesis occurs must necessarily violate either higher-ranked $\operatorname{DEP}(\mu)$ 
by inserting a mora or higher-ranked $\operatorname{MAxLINK}(\mu / \mathrm{V})$ by shortening the vowel. ${ }^{9}$

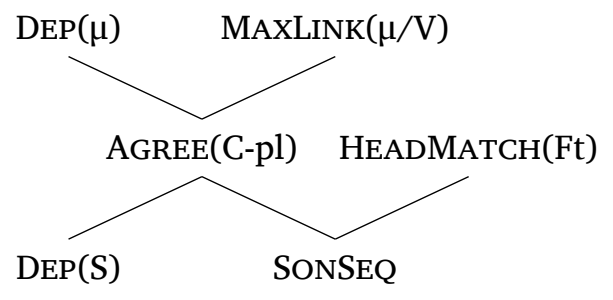

\section{3 /ə/-syncope and svarabhakti}

In §3.3 I argued that /ə/-syncope in Scottish Gaelic is not a synchronically productive phonological process, but rather involves suppletive stem allomorphy. Therefore a form such as fairchidh [far'áx $x^{j}-\mathrm{i}$ ] 'feel-NPST' is derived from a monosyllabic stem allomorph $/$ far ${ }^{j} \mathrm{x}^{\mathrm{j}} /$, rather than the disyllabic allomorph $/ \mathrm{far}^{\mathrm{j}} \mathrm{x}^{\mathrm{j}} /$ found in unsuffixed forms. This part of the analysis will assume the following additional constraint, which is common in the phonological literature:

(51) *LAPSE: Let $\sigma_{1} \sigma_{2}$ be a sequence of two adjacent syllables in the output. Assign a violation mark if neither $\sigma_{1}$ nor $\sigma_{2}$ is stressed.

I assume that, in items with two listed stem allomorphs, both allomorphs are evaluated in parallel in the phonology and "LAPSE motivates the selection of the monosyllabic stem allomorph in suffixed forms. A form such as fairchidh [far'áx ${ }^{\mathrm{j}}$-i] 'feel-NPST' therefore has the competing word-level inputs $\left[\mathrm{fa}_{\mu} \mathrm{r}^{\mathrm{j}} \partial_{\mu} \mathrm{x}^{\mathrm{j}}+\mathrm{i}\right]$ and $\left[\mathrm{fa}_{\mu} \mathrm{r}_{\mu}^{\mathrm{j}} \mathrm{x}^{\mathrm{j}}+\mathrm{i}\right]$ :

$$
\text { Input 1: } \quad \text { Input 2: }
$$

\footnotetext{
${ }^{9}$ Note that the constraint *LAPSE, defined in the next section, could also be responsible for the blocking of candidates (b) and (c) in (50). This is true only because the cluster is followed here by an unstressed syllable, but *LAPSE would fail to block epenthesis in a hypothetical monosyllabic form $* / \mathrm{L}^{\mathrm{j}} \mathrm{u}_{\mu \mu} \mathrm{rp} /$. I am aware of no monosyllabic items that exemplify the blocking of svarabhakti after a long vowel; however, it is unsafe to view this as anything more than an accidental gap, and therefore I will not rely on *LAPSE to motivate the elimination of these candidates here.
} 

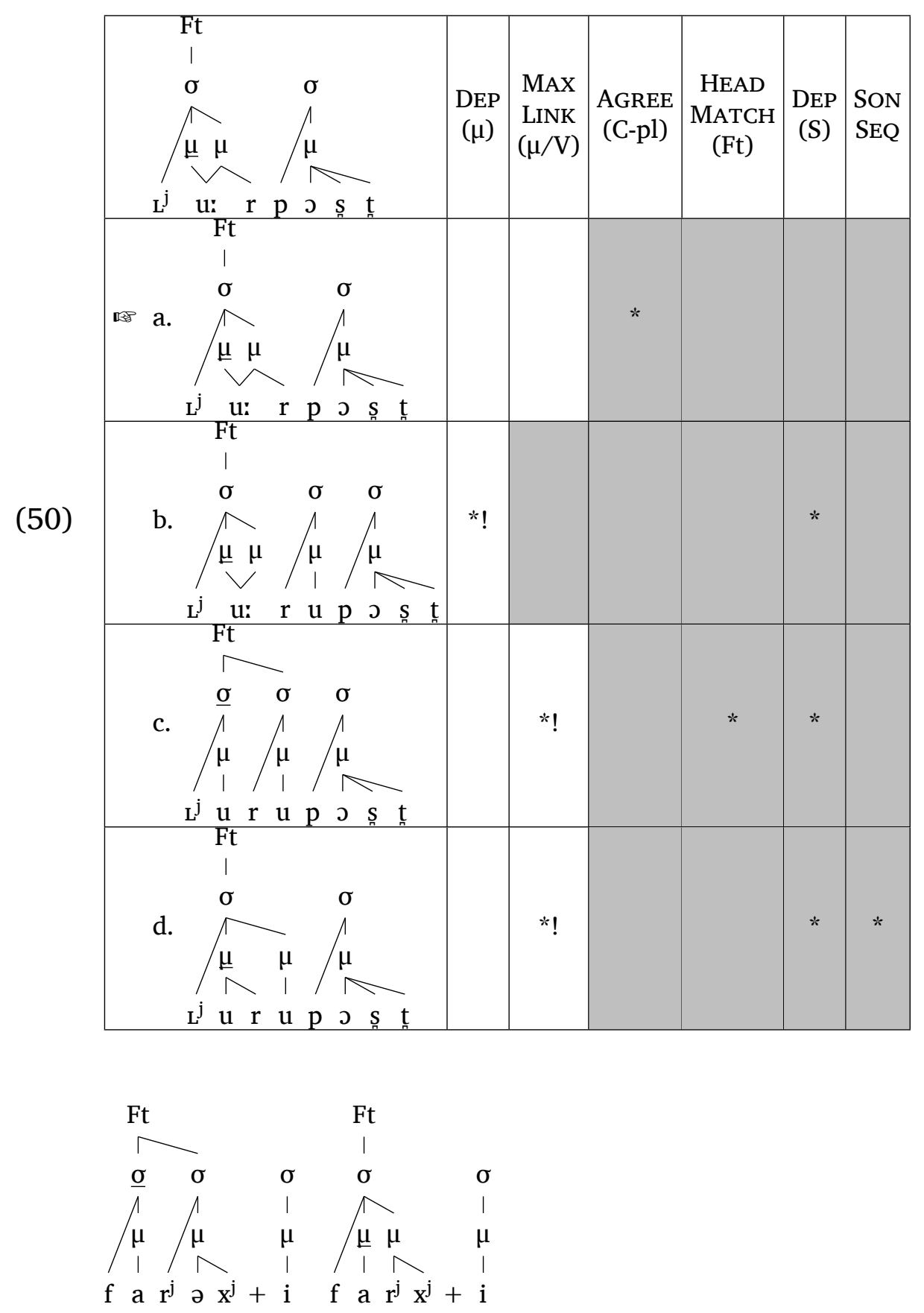

If we add to the partial word-level ranking in (49) by ranking *LAPSE above both $\operatorname{DEP}(\mathrm{S})$ and SONSEQ, as in (53), then we obtain the observed result, as shown in the tableau in (54). Highly-ranked *LAPSE ensures that a form 
is selected containing the monosyllabic stem allomorph, and svarabhakti proceeds as normal.

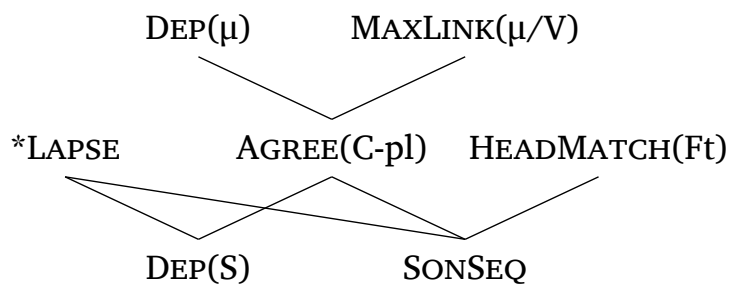

\section{The realisation of the Class 1-Class 2 con- trast}

This part of the analysis explores the ways in which the C1-C2 contrast is realised in different dialects of Scottish Gaelic. Pitch and duration are discussed together in §6.1, and glottalisation in §6.2, showing how the various surface manifestations of the contrast correspond to the differing metrical structures established in $\S 2$.

\subsection{Pitch and duration}

The distinction between $\mathrm{C} 1$ and $\mathrm{C} 2$ forms is reflected in Lewis Gaelic primarily by means of tone (Borgstrøm 1940: 53-54; Oftedal 1956: 25-27; Ladefoged et al. 1998; Brown 2009; Nance 2015). C1 forms-in which the stressed syllable is monomoraic - can usually be said to display a rising pitch on the first mora, while $\mathrm{C} 2$ forms - in which the stressed syllable is dimoraic-display a rising pitch spread across the first two morae; the pitch then falls sharply on any following syllable. As a result, a pitch peak can be said to occur on the rightmost mora of the stressed syllable. ${ }^{10}$ As well as in Lewis, this realisation of the C1-C2 contrast is also found in parts of Ross-shire (Borgstrøm 1941: 89; Wentworth 2005: 15-17). In accordance with recent analyses of tonal accent in Swedish (Morén-Duolljá 2013) and Franconian (Köhnlein 2011; 2016;

\footnotetext{
${ }^{10}$ Monomoraic forms such as corp [ $\mathrm{k}^{\mathrm{h}}$ jórp] 'body' display a rising pitch on their only mora and can thus be redundantly assigned to $\mathrm{C}$.
} 


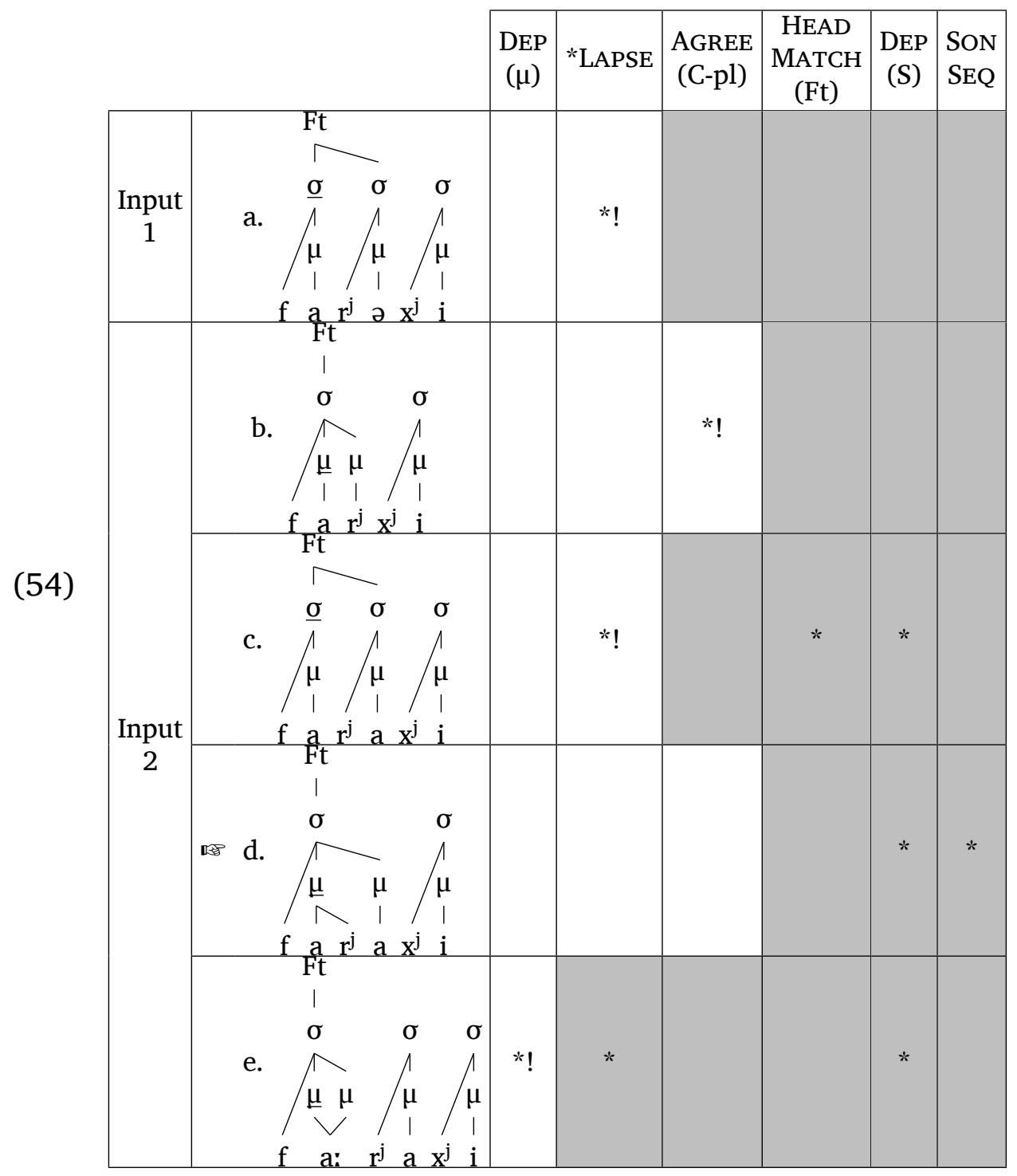

2017; Hermans 2012; Kehrein 2017), this tonal contrast can be analysed as reflecting not lexical tone but rather the alignment of intonational tonal autosegments with differing metrical structures in the phrase-level phonology. On the basis of the instrumental data presented by Ladefoged et al. (1998) for Bernera Gaelic, Ladefoged (2003: 275) suggests that, in isolated citation forms at least, the stressed syllable is assigned a LH tonal 
contour followed by a trailing $\mathrm{L}$ tone on any following unstressed syllable. Since the stressed syllable contains only the first mora in $\mathrm{C} 1$ forms and the first two morae in C2, this brings about the observed differences in the timing of the pitch peak, which is always aligned with the right edge of the stressed syllable. However, it is likely that a certain amount of variation exists according to dialect and phrasal context. Borgstrøm's (1940: 53-54) impressionistic description of Bernera Gaelic intonation very closely matches Ladefoged et al.'s (1998) instrumental results, but he specifies that the pitch rise on the stressed syllable is often "very reduced" in phrase-final position. This suggests the presence of a $\mathrm{L} \%$ boundary tone which may suppress the $\mathrm{H}$ tone of the stressed syllable. Meanwhile, Oftedal's (1956: 26-27) description of Leurbost Gaelic notes that the stressed syllable may be either rising or high, suggesting that the first L tone may not always be realised. Interestingly, in an instrumental study on Ness Gaelic encompassing a variety of phrasal contexts, Brown (2009) finds that words in focus position display essentially the opposite tonal pattern to that assumed throughout this paper, with the right edge of the stressed syllable displaying a pitch trough followed by a sharp rise on the following syllable; meanwhile, no pitch differences are reported for non-focus, non-final contexts. In all of these cases, however, the accent contrast can be described in terms of the alignment of intonational tones with either monomoraic or dimoraic stressed syllables.

Unlike in Lewis, C1 and C2 forms are distinguished in Applecross, Rossshire primarily by means of duration (Borgstrøm 1941: 128-129; Ternes 1973: 102-107). C1 forms display normal length, while C2 forms display overlength through elongation of the second mora:

Lewis Applecross

a. C1:

$\begin{array}{lll}\text { dubhan [túan] } & \text { [tuan] } & \text { 'hook' } \\ \text { bodha [pô:] } & \text { [po:] } & \text { 'submerged rock' } \\ \text { aran [áran] [aran] } & \text { 'bread' }\end{array}$

b. C2:

$\begin{array}{llll}\text { uan } & \text { [uán] } & \text { [ua'n] } & \text { 'lamb' } \\ \text { bò } & \text { [pǒ:] } & \text { [po:'] } & \text { 'cow' } \\ \text { arm } & \text { [arám] } & {[\text { ara'm] }} & \text { 'army' }\end{array}$

However, Ternes (2006: ch. 5) reports a slight difference in pitch contour 
accompanying this durational distinction: $\mathrm{C} 1$ forms display a single early pitch peak followed by a sharp fall just as in Lewis, while C2 forms display a subtly double-peaked but overall more level pitch contour. Conversely, Brown (2009) reports differences in both duration and intensity accompanying the tonal contrast between $\mathrm{C} 1$ and $\mathrm{C} 2$ forms in Lewis Gaelic, and these differences remain even in non-focus, non-final contexts where no difference in pitch is reported. In Barra Gaelic, where the primary cue appears to be more difficult to pin down, Bosch \& de Jong (1997) find differences in both pitch and duration between svarabhakti groups and ordinary 'VCV sequences: svarabhakti groups display a later pitch peakalthough not as late as in Lewis-and svarabhakti vowels are longer. As discussed in detail by Köhnlein (2015), close relationships between pitch and duration are common cross-linguistically. For instance, in many Franconian dialects, the sharply falling pitch of Accent 1 is accompanied by considerably shorter duration than the more level Accent 2 , and in certain phrasal contexts duration may even replace pitch as the primary cue to the contrast (Gussenhoven \& Peters 2004; Peters 2006)—similar to Brown's (2009) findings for Ness Gaelic. The opposite pattern is found in Estonian, in which overlength is associated with falling pitch (Lehiste 1960). Interactions between pitch and duration are also known to occur in Swedish and Norwegian (Gårding 1977: 44), Serbo-Croatian (Lehiste \& Ivić 1986: $59 \mathrm{ff}$.) and Livonian (Kiparsky 2017). Since it is clear that a trade-off between pitch and durational cues is often involved in the realisation of a single phonological opposition, there is no need to ascribe the Lewis and Applecross forms in (55) to different phonological surface representations. I therefore assume that Lewis and Applecross Gaelic differ only at the phonetic level with respect to the C1-C2 opposition. While Lewis Gaelic assigns greater weight to pitch in the phonetic interpretation of tone, Applecross Gaelic favours durational cues. Barra Gaelic can be taken to represent an intermediate dialect, in which pitch and duration are assigned more equal importance.

\subsection{Glottalisation}

While the dialects of the Outer Hebrides, Skye and Ross-shire distinguish C1 and C2 forms primarily by means of various combinations of pitch and duration, glottalisation may also play a small role in the realisation 
of the contrast. Throughout this region, Borgstrøm (1937: 74-77; 1940: 55-56, 152-153; 1941: 32, 89) reports the occurrence of a slight "break in tension" between the first and second morae of $\mathrm{C} 1$ forms, which in Barra may even be realised as a full "glottal catch" in hiatus sequences. In many Argyll dialects, including those of Islay (Holmer 1938), Jura (Jones 2000; 2006; 2010) and Colonsay (Scouller 2017), the C1-C2 contrast is realised exclusively by means of glottalisation. $\mathrm{C} 1$ forms display a period of glottalisation between the first two morae while C2 forms do not:

$$
\text { Lewis Islay }
$$

a. C1:

$$
\begin{aligned}
& \text { dubhan [ț́an] }\left[\mathrm{tu}^{2} \mathrm{an}\right] \text { 'hook' } \\
& \text { bodha [pô:] [po }\left[\mathrm{po}^{2} \mathrm{u}\right] \text { 'submerged rock' } \\
& \text { aran [áran] [a'ran] 'bread' }
\end{aligned}
$$

b. C2:

$$
\begin{array}{llll}
\text { uan } & \text { [uán] } & \text { [uan] } & \text { 'lamb' } \\
\text { bò } & \text { [pǒ:] } & \text { [pou] } & \text { 'cow' } \\
\text { arm } & \text { [arám] } & \text { [arəm] 'army' }
\end{array}
$$

The distribution of glottalisation on vowels and sonorants in Argyll Gaelic exactly matches the distribution of the two tonal contours in Lewis. However, in order to determine the general distribution of glottalisation, it is necessary to take a closer look at its occurrence on obstruents. In Lewis Gaelic, a 'VCV sequence containing an obstruent is always disyllabic and therefore bears the first-mora pitch peak of C1. According to SGDS, Jones

\begin{tabular}{|c|c|}
\hline litir & {$\left[\mathrm{L}^{\mathrm{j}} \mathrm{ih} \mathrm{t}^{\mathrm{j}} \partial \mathrm{r}\right]$} \\
\hline socair & [soxkər] \\
\hline
\end{tabular}
(2000; 2006; 2010) and Scouller (2017), glottalisation occurs as expected in Argyll when the obstruent is a plain stop or a voiced fricative, but not when it is a pre-aspirated stop (realised as a voiceless fricative + plain stop cluster in this dialect) or a voiceless fricative:

(57) Islay (SGDS)

a. Pre-aspirated stop ( $\rightarrow$ fricative + plain stop):

b. Plain stop:

bradan [pra'țan] 'salmon' 


\begin{tabular}{|c|c|c|}
\hline & $\begin{array}{ll}\text { cogadh } & {\left[\mathrm{k}^{\mathrm{h}} \mathrm{o}^{2} \mathrm{k} \gamma \mathrm{\gamma}\right]} \\
\text { leabaidh } & {\left[\mathrm{L}^{\mathrm{j}} \mathrm{a}^{2} \mathrm{pi}\right]}\end{array}$ & $\begin{array}{l}\text { 'war' } \\
\text { 'bed' }\end{array}$ \\
\hline \multirow[t]{4}{*}{ c. } & Voiceless fricative: & \\
\hline & drochaid [troxว $\left.\mathrm{t}^{\mathrm{j}}\right]$ & 'bridge' \\
\hline & seasamh [[esəv] & 'stand.vN' \\
\hline & toiseachd $\left[\mathrm{t}^{\mathrm{h}} \mathrm{o} \int \partial \mathrm{xk}\right]$ & 'beginning' \\
\hline d. & Voiced fricative: & \\
\hline & fiodhan [fium $\left.{ }^{2} y a n\right]$ & 'cheese-press' \\
\hline & $\begin{array}{ll}\text { sabhal } & {\left[\mathrm{sa}^{2} \mathrm{v} \nu \mathrm{L}\right]} \\
\text { sogmhan } & {\left[\mathrm{ske}^{2} \mathrm{van}\right]}\end{array}$ & $\begin{array}{l}\text { 'byre' } \\
\text { 'lung' }\end{array}$ \\
\hline & sgamnan [S్nKe ${ }^{1}$ van] & lung \\
\hline
\end{tabular}

I assume that pre-aspirated stops and voiceless fricatives in Scottish Gaelic bear the feature [ + spread glottis] while other consonants do not. Given the foot structures proposed in $\$ 2.3$, we can make the generalisation that glottalisation occurs whenever two syllables are parsed into a single foot, unless they are separated by a [ + spread glottis] consonant. Glottalisation, which I assume to consist of epenthesis of [ + constricted glottis], may represent a process of fortition that serves to enhance the boundary between two syllables that are in particularly close metrical contact, i.e. share a foot, although this would run contrary to the cross-linguistic tendency for foot-medial consonants to be targets for lenition rather than fortition. Presumably, it is blocked by the presence of [+ spread glottis] because these two features are articulatorily incompatible with one another.

Smith (1999), Hall (2003; 2006) and Iosad (2015) offer a different analysis of the distribution of glottalisation in Argyll Gaelic, regarding it as a segmental glottal stop inserted in the coda of a stressed monomoraic syllable in order to render it dimoraic and thus satisfy a stress-to-weight (STW) condition. Scouller (2017) reaches a similar conclusion, although he regards glottalisation as suprasegmental. The STW analysis of glottalisation appears to be primarily motivated by Holmer's (1938: 36-37) claim that it occurs at the end of short open monosyllables, e.g. teth [ $\left.\mathrm{t}^{\mathrm{jh}} \mathrm{e}^{\mathrm{l}}\right]$ ' hot', math $\left[\mathrm{m} \varepsilon^{2}\right]$ 'good'. However, all other first-hand accounts disagree with Holmer on this vital point. ${ }^{11}$ Glottalisation in this environment is not reported by Jones (2000; 2006; 2010) for Jura Gaelic and is not recorded in SGDS for

\footnotetext{
${ }^{11}$ The system described by Holmer (1938) differs from other accounts in a number of important ways. For instance, fortis sonorants are geminate not only in the coda but also intervocalically, and glottalisation does not affect obstruents.
} 
any dialect. Scouller (2017) himself finds that it does not occur in this environment in Colonsay, but is forced by his own analysis to conclude that it must be "at least notionally present in such cases" (p. 261). Under the STW approach, the absence of glottalisation in the forms in (57a) is taken to be because the voiceless fricatives are moraic codas, which is at odds with the present analysis. However, the forms in (57c) show that voiceless fricatives block glottalisation even when they are not codas, which none of these authors accounts for. Yet another problem for the STW approach is that it requires that glottalisation serve as a moraic coda even when intervocalic, i.e. in hiatus forms such as dubhan [tu' an] 'hook', bodha [po ${ }^{2} \mathrm{u}$ ' 'submerged rock', which would involve extremely unusual leftward syllabification of an intervocalic consonant. ${ }^{12}$ I therefore conclude that glottalisation in Argyll Gaelic is best analysed as marking the boundary between two syllables that share a foot, unless they are separated by a [+ spread glottis] consonant.

\section{Discussion}

In this section I offer some general discussion of the analysis presented in this paper. $\$ 7.1$ outlines other analyses of the C1-C2 contrast in Scottish Gaelic and evaluates them against the present analysis. \$7.2 places this analysis of Scottish Gaelic in its wider context by exploring how it relates to existing metrical analyses of tonal accent, glottalisation and overlength in languages such as Swedish, Danish, Franconian and Estonian.

\subsection{Other analyses}

The claim that the C1-C2 contrast in Scottish Gaelic reflects metrical structure has been put forward by numerous authors in the past. However, analyses disagree on the exact nature of the metrical structures involved and

\footnotetext{
${ }^{12}$ The reader may be aware that Borgstrøm $(1937 ; 1940 ; 1941)$ describes VC.V syllabification as characteristic of $\mathrm{C} 1$ forms in Scottish Gaelic, a claim repeated in a few other accounts (Holmer 1957; 1962; Dilworth 1972; see Bosch 1998 for a detailed review). Borgstrøm bases this assertion on his perception of a "break in tension" towards the end of the consonant, which he interprets as the phonetic manifestation of a syllable boundary but which most probably just represents glottalisation. There is no phonological evidence for VC.V syllabification in Scottish Gaelic and it is not considered in this paper.
} 
the manner in which they are derived, particularly with regard to svarabhakti groups. Some authors tackle the problem by viewing svarabhakti vowels as entirely non-phonological. Iosad (2015) analyses svarabhakti as a purely phonetic process, so that svarabhakti vowels are invisible to the surface phonology and are therefore unable to project a syllable of their own. Within the framework of Articulatory Phonology, Hind (1996; 1997) and Hall $(2003 ; 2006)$ ascribe svarabhakti to the relative realignment of overlapping articulatory gestures, which causes a consonantal gesture to occur in the middle of a single long vocalic gesture. However, these approaches have difficulty dealing with the various cases of opacity in svarabhakti, such as the apparent overapplication before hiatus in (13) and the underapplication in sonorant $+[\mathrm{h}]$ clusters in (14) or before Barra Gaelic [xk] in (36). Hall's (2003) analysis is equipped with a means to account for lexically specific overapplication of svarabhakti, but she does not consider these cases of underapplication. Clearly, any successful account of svarabhakti must be capable of handling its complex interactions with other phonological processes.

Some authors propose complex multi-layered structures to represent the contrast between $\mathrm{C} 1$ and $\mathrm{C} 2$ forms. On the basis of phonetic data from Barra Gaelic, Bosch \& de Jong (1998) argue that each of the two vowels in a svarabhakti group heads a syllable within a larger domain which they term a "super-syllable". The existence of the lower "syllable" level—at which the two vowels in a svarabhakti group belong to separate domains-is based on an observed asymmetry between the two vowels with respect to both stress and backness. Specifically, svarabhakti vowels in Barra Gaelic display greater stress than the preceding vowel according to phonetic criteria such as pitch and duration, and receive their backness specification from the intervening consonant rather than from the preceding vowel. However, it is not clear why the phonetic correlates of stress should be expected to remain constant throughout the duration of a stressed syllable, nor is there any reason why two vowels in a single syllable should necessarily agree in backness. There is therefore very little motivation for positing an entirely new level of prosodic representation, instead of simply equating the higher-level domain-which contains both vowels in a svarabhakti group-with a traditional syllable.

Smith (1999) argues that a svarabhakti vowel heads a syllable that is recursively embedded within a larger syllable headed by the preceding vowel. The embedded syllable is posited for theory-internal reasons 
and Smith does not justify its existence using data from Scottish Gaelic. Although this representation can account for the monosyllabic nature of svarabhakti groups, the derivational part of Smith's analysis relies on a family of constraints whose precise definitions are unclear. For instance, the constraint SONCSEP is stated as follows:

(58) SONCSEP: A cluster of a sonorant consonant and any non-syllabic must be separated by an epenthetic vowel, i.e. must form a recursive syllable with an explicit nucleus. One of the two elements in the cluster must be non-coronal. (Smith 1999: 613)

Contrary to the core principles of Optimality Theory, this constraint simultaneously states not only the output structure that it disfavours (a particular type of cluster) but also the repair that is to be carried out in order to satisfy it (insertion of an epenthetic vowel in a recursively embedded syllable). If we attempt to convert this into a standardly formulated markedness constraint targeting clusters of the appropriate type, we are left with no motivation for placing the epenthetic vowel in a recursively embedded syllable rather than an ordinary non-embedded one. Smith's analysis therefore brings us no closer to understanding how the special prosodic properties of svarabhakti groups might be derived.

Not all analyses of the C1-C2 contrast in Scottish Gaelic involve metrical structure. Ternes (1980; 2006: ch. 5) argues that Scottish Gaelic has lexical tone and draws a comparison with other northern European languages, such as Swedish and Norwegian, for which tonal analyses were predominant at the time. However, this approach does not account for the many ways, discussed in $\S 2.2$ and §3.1, in which the C1-C2 contrast interacts with segmental structure. A very different non-metrical analysis is offered by Stanton \& Zukoff (2018), who regard the special prosodic properties of svarabhakti groups as reflecting the fact that both vowels are stressed. The presence of stress on both vowels in a svarabhakti group is of course consistent with the present analysis, and forms part of many impressionistic descriptions of the C1-C2 contrast for various Scottish Gaelic dialects (Fraser 1914; Borgstrøm 1937; 1940; 1941; Oftedal 1956; Dilworth 1972; Wentworth 2005). However, rather than regarding both vowels as belonging to a single stressed syllable, Stanton \& Zukoff ascribe this stress pattern to correspondence constraints that motivate identity between epenthetic vowels and their hosts with respect to prosodic properties. As discussed by 
Morrison (2018b), this analysis is problematic because it considers svarabhakti in isolation rather than in the wider context of the C1-C2 contrast, and some aspects of the analysis rely on incorrect assumptions about the distribution of vowel length in Scottish Gaelic.

\subsection{Wider context}

In ascribing the the C1-C2 contrast in Scottish Gaelic to differences in metrical structure, the analysis presented in this paper bears a degree of similarity to analyses proposed for contrasts of tone, glottalisation and overlength in other languages. Morén-Duolljá (2013) argues that Swedish words with Accent 2 contain a recursive foot while those with Accent 1 do not, and the tonal accent opposition results from the alignment of intonational tones with these differing metrical structures. Meanwhile, Iosad (2016) analyses Danish stød as reflecting recursive foot structure in a similar manner. As for Franconian, Hermans (2012) and Kehrein (2017) analyse Accent 1 words as containing a monosyllabic foot and Accent 2 words a disyllabic foot, whereas Köhnlein $(2011 ; 2016 ; 2017$; 2018) proposes the opposite. Finally, Prince (1980) and Odden (1997) argue that long syllables in Estonian belong to a disyllabic foot while overlong syllables consititute a foot on their own. Although the exact nature of the relevant contrast varies from one account to another, what unites the present analysis with most of the aforementioned analyses is that the surface contrast is mediated through faithfulness to foot structure.

While most of these analyses derive the relevant surface contrasts through faithfulness to metrical structure that is lexically stored, the present analysis shows, using the framework of Stratal Optimality Theory, that the surface contrast between C1 and C2 forms in Scottish Gaelic is predictable on the basis of their underlying segmental content. In this respect, this account bears a striking similarity to van Oostendorp's (2017) analysis of tonal accent on pre-obstruent short vowels in Moresnet Franconian. According to his analysis, metrical structure is built at the stem level and is sensitive to the voicing specification of the obstruent, but may subsequently be rendered opaque by final devoicing or voice assimilation at the word level. In diachronic terms, when viewed in the light of the life cycle of phonological processes (Bermúdez-Otero 2015), it can be assumed that languages displaying contrastive metrical structure 
must at one time have gone through a similar stage, where metrical structure ceased to be completely surface-true and began interacting opaquely with phonological or morphological processes before eventually undergoing lexicalisation. Scottish Gaelic can therefore be regarded as a missing link in the evolution of lexically contrastive metrical structure.

By highlighting the connection between tonal accent, glottalisation and overlength in different dialects of Scottish Gaelic, the present analysis hopes to help consolidate the relationship between these three phenomena in other languages in which they occur. As discussed in \$6.1, the link between tone and duration is well-known. Köhnlein (2015) proposes a recurring diachronic pathway in which phonetically longer units first come to bear more complex tonal contours. A tendency to lengthen units with level tones then results in a durational reversal, so that the originally shorter unit becomes the longer one. A language in which longer duration is associated with a contour tone, e.g. Estonian, can be assumed to lie at an early stage of this pathway, while one in which longer duration is associated with a more level tone, e.g. Franconian, represents a later stage. Applying this to Scottish Gaelic, it appears that Applecross, Ross-shire represents a particularly progressive dialect in which the relatively level tone of C2 forms has been replaced by longer duration. As for the link between tone and glottalisation, it is known that the sharp pitch fall inherent in a HL tonal contour is liable to result in creaky voice (e.g. Lindblom 2009; Riad 2009). The cognate relationship between the typically early-peaked Accent 1 of Swedish and stød in Danish is clearly paralleled by the C1-C2 contrast in Scottish Gaelic, where C1 is characterised by both an early pitch peak in Lewis and glottalisation in Argyll. Finally, the various realisations of the C1-C2 contrast in Scottish Gaelic are perfectly matched in Livonian, in which one of two phonological classes is distinguished from the other by means of a simultaneous combination of falling pitch, glottalisation and shorter duration (Kiparsky 2017).

\section{Conclusion}

This paper has used the framework of Stratal Optimality Theory to build a complete and thorough analysis of the C1-C2 contrast in Scottish Gaelic, which is realised by means of tonal accent, glottalisation or overlength depending on dialect. In line with a number of recent analyses of simi- 
lar phonological oppositions in other languages of northern Europe, this contrast was ascribed to differences in metrical structure. It was shown that metrical structure in Scottish Gaelic is built in the phonology in a regular manner, but may be rendered opaque by complex interactions with other phonological processes. This results in the observed surface contrast between $\mathrm{C} 1$ and $\mathrm{C} 2$ forms. In $\S 7$ it was argued that this analysis outperforms others at explaining the extremely complex facts of Scottish Gaelic phonology. It was also argued that Scottish Gaelic can be thought of as representing an intermediate stage in the diachronic trajectory that led to the lexically contrastive metrical structure observed in other languages today, and can inform us about the relationship between the oppositions of tone, glottalisation and overlength found in those languages. The contrast between C1 and C2 forms in Scottish Gaelic is but one of the myriad ways in which the astonishing intricacies of the Scottish Gaelic sound system can enhance our understanding of the kinds of phonological phenomena that occur in the languages of the world.

\section{References}

Anderson, Cormac. 2016. Consonant colour and vocalism in the history of Irish. Poznań: Adam Mickiewicz University dissertation.

Bermúdez-Otero, Ricardo. 2015. Amphichronic explanation and the life cycle of phonological processes. In Patrick Honeybone \& Joseph C. Salmons (eds.), The Oxford handbook of historical phonology, 374-399. Oxford: OUP.

Bermúdez-Otero, Ricardo. 2018. Stratal Phonology. In S. J. Hannahs \& Anna R. K. Bosch (eds.), The Routledge handbook of phonological theory, 100-134. Abingdon: Routledge.

Borgstrøm, Carl Hj. 1937. The dialect of Barra in the Outer Hebrides. Norsk Tidsskrift for Sprogvidenskap 8. 71-242.

Borgstrøm, Carl Hj. 1940. The dialects of the Outer Hebrides (A Linguistic Survey of the Gaelic Dialects of Scotland 1). Oslo: Norwegian Universities Press.

Borgstrøm, Carl Hj. 1941. The dialects of Skye and Ross-shire (A Linguistic Survey of the Gaelic Dialects of Scotland 2). Oslo: Norwegian Universities Press. 
Bosch, Anna R. K. 1994. Syncope and epenthesis in Scottish Gaelic: Rules and phonotactics. In A. Davidson, N. Maier, G. Silva \& W S. Yan (eds.), FLSM IV: Papers from the Fourth Annual Meeting of the Formal Linguistics Society of Midamerica: April 15-18, 1993, 35-47. Bloomington, IN: Indiana University Linguistics Club.

Bosch, Anna. 1998. The syllable in Scottish Gaelic dialect studies. Scottish Gaelic Studies 18. 1-22.

Bosch, Anna R. K. 2010. Phonology in Modern Gaelic. In Moray Watson \& Michelle Macleod (eds.), The Edinburgh companion to the Gaelic language, 262-282. Edinburgh: EUP.

Bosch, Anna \& Kenneth de Jong. 1997. The prosody of Barra Gaelic epenthetic vowels. Studies in the Linguistic Sciences 27(1). 1-15.

Bosch, Anna \& Kenneth de Jong. 1998. Syllables and supersyllables: Evidence for low level prosodic domains. In Amanda R. Doran, Tivoli Majors, Claude A. Mauk \& Nisha Merchant Goss (eds.), Exploring the boundaries between phonetics and phonology: Proceedings of the 1998 Texas Linguistics Society Conference (Texas Linguistic Forum 41), 1-14. Austin, TX: Department of Linguistics, The University of Texas at Austin.

Branderud, Peter \& Hartmut Traunmüller (eds.). 2009. Proceedings of FONETIK 2009: The XXIIth Swedish Phonetics Conference, June 10-12, 2009. Stockholm: Department of Linguistics, Stockholm University.

Broselow, Ellen, Su-I Chen \& Marie Huffman. 1997. Syllable weight: Convergence of phonology and phonetics. Phonology 14(1). 47-82.

Brown, Morag. 2009. An investigation into prosodic patterns in the Ness dialect of Scottish Gaelic. Edinburgh: University of Edinburgh dissertation.

Clements, G. N. 1986. Syllabification and epenthesis in the Barra dialect of Gaelic. In Koen Bogers, Harry van der Hulst \& Maarten Mous (eds.), The phonological representation of suprasegmentals: Studies on African languages offered to John M. Stewart on his 60th birthday, 317-36. Dordrecht / Cinnaminson, NJ: Foris.

Dilworth, Anthony. 1972. Mainland dialects of Scottish Gaelic. Fort Augustus: Abbey Press.

Dorian, Nancy C. 1978. East Sutherland Gaelic: The dialect of the Brora, Golspie and Embo fishing communities. Dublin: DIAS.

Fraser, J. 1914. Accent and svarabhakti in a dialect of Scotch Gaelic. Revue Celtique 35. 401-409.

Gårding, Eva. 1977. The Scandinavian word accents (Travaux de l'Institut de Linguistique de Lund 11). Lund: Gleerup. 
Gillies, William. 2009. Scottish Gaelic. In Martin J. Ball \& Nicole Müller (eds.), The Celtic languages Routledge Language Family Series, 230-304. Abingdon, Oxon.: Routledge 2nd edn.

Grannd, Seamas. 1985. Some distinguishing features of the Gaelic of Islay. Scottish Language 4. 19-31.

Grannd, Seamas. 2000. The Gaelic of Islay: A comparative study. Aberdeen: Department of Celtic, University of Aberdeen.

Green, Anthony Dubach. 1997. The prosodic structure of Irish, Scots Gaelic, and Manx. Ithaca, NY: Cornell University dissertation.

Gussenhoven, Carlos \& Jörg Peters. 2004. A tonal analysis of Cologne Schärfung. Phonology 21(2). 251-285.

Gussmann, Edmund. 1986. Autosegments, linked matrices and the Irish lenition. In Dieter Kastovsky \& Aleksander Szwedek (eds.), Linguistics across historical and geographical boundaries: In honour of Jacek Fisiak on the occasion of his fiftieth birthday (Trends in Linguistics: Studies and Monographs 32), 891-907. Berlin: Mouton de Gruyter.

Hall, Nancy Elizabeth. 2003. Gestures and segments: Vowel intrusion as overlap. Amherst, MA: University of Massachusetts dissertation.

Hall, Nancy. 2006. Cross-linguistic patterns of vowel intrusion. Phonology 23(3). 387-429.

Halle, Morris. 1995. Feature geometry and feature spreading. LI 26(1). 1-46.

Halle, Morris, Bert Vaux \& Andrew Wolfe. 2000. On feature spreading and the representation of place of articulation. LI 31(3). 387-444.

Hammond, Michael, Natasha Warner, Andréa Davis, Andrew Carnie, Diana Archangeli \& Muriel Fisher. 2014. Vowel insertion in Scottish Gaelic. Phonology 31(1). 123-153.

Hayes, Bruce. 1989. Compensatory lengthening in moraic phonology. $L I$ 20(2). 253-306.

Hayes, Bruce. 1995. Metrical Stress Theory: Principles and case studies. Chicago: University of Chicago Press.

Hermans, Ben. 2012. The phonological representation of the Limbugian tonal accents. In Bert Botma \& Roland Noske (eds.), Phonological explorations: Empirical, theoretical and diachronic issues, 223-240. Berlin: De Gruyter.

Hind, Kevin. 1996. The structure of epenthesis in Gaelic. Journal of Celtic Linguistics 5. 91-119. 
Hind, Kevin. 1997. Phonologising Articulatory Phonology. Edinburgh: University of Edinburgh dissertation.

Holmer, Nils M. 1938. Studies on Argyllshire Gaelic. Skrifter Utgivna av K. Humanistiska Vetenskaps-Samfundet i Uppsala 31.

Holmer, Nils M. 1957. The Gaelic of Arran. Dublin: DIAS.

Holmer, Nils M. 1962. The Gaelic of Kintyre. Dublin: DIAS.

Hyde, Brett. 2011. The iambic-trochaic law. In Marc van Oostendorp, Colin J. Ewen, Elizabeth Hume \& Keren Rice (eds.), The Blackwell companion to phonology, 1052-1077. Oxford: Blackwell.

Iosad, Pavel. 2015. 'Pitch accent' and prosodic structure in Scottish Gaelic: Reassessing the role of contact. In Martin Hilpert, Jan-Ola Östman, Christine Mertzlufft, Micheal Rießler \& Janet Duke (eds.), New trends in Nordic and general linguistics, 28-54. Berlin: Mouton de Gruyter.

Iosad, Pavel. 2016. Prosodic structure and segmental features: Short-vowel stød in Danish. Journal of Comparative Germanic Linguistics 19(3). 221268.

Jones, George. 2000. Beagan mu'n stad ghlotasach ann an Gàidhlig ceann a deas Earraghaidheil. Scottish Gaelic Studies 20. 201-211.

Jones, George. 2006. Cunntas air an stad ghlotasach ann an Gàidhlig cheann a deas Earra Ghàidheil. In Wilson McLeod, James E. Fraser \& Anja Gunderloch (eds.), Cànan \& cultar / Language \& culture (Rannsachadh na Gàidhlig 3), 193-202. Edinburgh: Dunedin Academic Press.

Jones, George. 2010. The Gaelic of Jura: A description. Aberystwyth: Aberystwyth University dissertation.

Kehrein, Wolfgang. 2017. There's no tone in Cologne: Against tonesegment interactions in Franconian. In Kehrein et al. (2017) 147-194.

Kehrein, Wolfgang, Björn Köhnlein, Paul Boersma \& Marc van Oostendorp (eds.). 2017. Segmental structure and tone (Linguistische Arbeiten 552). Berlin: De Gruyter.

Kiparsky, Paul. 2000. Opacity and cyclicity. The Linguistic Review 17. 351365.

Kiparsky, Paul. 2017. Livonian stød. In Kehrein et al. (2017) 195-210.

Köhnlein, Björn. 2011. Rule reversal revisited: Synchrony and diachrony of tone and prosodic structure in the Franconian dialect of Arzbach. Leiden: University of Leiden dissertation. 
Köhnlein, Björn. 2015. The complex durational relationship of contour tones and level tones: Evidence from diachrony. Diachronica 32(2). 231267.

Köhnlein, Björn. 2016. Contrastive foot structure in Franconian toneaccent dialects. Phonology 33(1). 87-123.

Köhnlein, Björn. 2017. Synchronic alternations between monophthongs and diphthongs in Franconian tone accent dialects: A metrical approach. In Kehrein et al. (2017) 211-235.

Köhnlein, Björn. 2018. A morpheme-based approach to subtractive pluralisation in German dialects. Phonology 35(4). 617-647.

Ladefoged, Peter. 2003. Commentary: Some thoughts on syllables-an old-fashioned interlude. In John Local, Richard Ogden \& Rosalind A. M. Temple (eds.), Papers in Laboratory Phonology VI, 269-276. Cambridge: CUP.

Ladefoged, Peter, Jenny Ladefoged, Alice Turk, Kevin Hind \& St. John Skilton. 1998. Phonetic structures of Scottish Gaelic. Journal of the International Phonetic Association 28. 1-41.

Lehiste, Ilse. 1960. Segmental and syllabic quality in Estonian. In American studies in Uralic linguistics (The Uralic and Altaic Series 1), 21-82. Bloomington, IN: Indiana University.

Lehiste, Ilse \& Pavle Ivić. 1986. Word and sentence prosody in Serbocroatian. Cambridge, MA: MIT Press.

Lindblom, Björn. 2009. F0 lowering, creaky voice, and glottal stop: Jan Gauffin's account of how the larynx works in speech. In Branderud \& Traunmüller (2009) 8-11.

MacAulay, Donald. 1992. The Scottish Gaelic language. In Donald MacAulay (ed.), The Celtic languages, 137-248. Cambridge: CUP.

McCarthy, John J. 1995. Extensions of faithfulness: Rotuman revisited. Ms.

McCarthy, John J. 2000. The prosody of phase in Rotuman. NLLT 18. 147-197.

McCarthy, John J. 2002. A thematic guide to Optimality Theory. Cambridge: CUP.

Morén, Bruce. 1999. Distinctiveness, coercion and sonority: A unified theory of weight. College Park, MD: University of Maryland, College Park dissertation.

Morén-Duolljá, Bruce. 2013. The prosody of Swedish underived nouns: No lexical tones required. Nordlyd 40(1). 196-248. 
Morrison, Donald Alasdair. 2018a. Ness Gaelic vowels and the broad/slender contrast. Paper presented at Rannsachadh na Gàidhlig 10, Edinburgh, 30th August 2018.

Morrison, Donald Alasdair. 2018b. Scottish Gaelic svarabhakti: Not evidence for prosodic identity in copy epenthesis. Paper presented at the 26th Manchester Phonology Meeting, Manchester, 24th May 2018.

Nance, Claire. 2015. Intonational variation and change in Scottish Gaelic. Lingua 160. 1-19.

Ní Chiosáin, Máire. 1991. Topics in the phonology of Irish. Amherst, MA: University of Massachusetts dissertation.

Ní Chiosáin, Máire. 1994. Barra Gaelic vowel copy and (non-)constituent spreading. In Raúl Aranovich, William Byrne, Susanne Preuss \& Martha Senturia (eds.), WCCFL 13, 3-15. Stanford, CA: CSLI.

Ó Baoill, Dónall P. 1980. Preaspiration, epenthesis and vowel lengthening-interrelated and of similar origin? Celtica 13. 79-108.

Odden, David. 1997. Some theoretical issues in Estonian prosody. In Ilse Lehiste \& Jaan Ross (eds.), Estonian prosody: Papers from a symposium, 165-195. Tallinn: Institute of Estonian Language.

Ó Dochartaigh, Cathair. 1980. Vowel strengthening in Gaelic. Scottish Gaelic Studies 8(2). 219-240.

Ó Dochartaigh, Cathair. 1994-1997. Survey of the Gaelic Dialects of Scotland: Questionnaire materials collected for the Linguistic Survey of Scotland [SGDS]. Dublin: DIAS.

Oftedal, Magne. 1956. The Gaelic of Leurbost, Isle of Lewis (A Linguistic Survey of the Gaelic Dialects of Scotland 3). Oslo: W. Aschehoug.

Ó Murchú, Máirtín. 1989. East Perthshire Gaelic: Social history, phonology, texts, and lexicon. Dublin: DIAS.

O'Rahilly, Thomas F. 1972. Irish dialects past and present: With chapters on Scottish and Manx. Dublin: DIAS 2nd edn.

Peters, Jörg. 2006. The Cologne word accent revisited. In Michiel de Vaan (ed.), Germanic tone accents: Proceedings of the First International Workshop on Franconian Tone Accents, Leiden, 13-14 June 2003, 107-133. Stuttgart: Steiner.

Prince, Alan. 1980. A metrical theory for Estonian quantity. LI 11(3). 511-562.

Riad, Tomas. 2009. Eskilstuna as the tonal key to Danish. In Branderud \& Traunmüller (2009) 12-17. 
Scouller, Alastair MacNeill. 2017. The Gaelic dialect of Colonsay. Edinburgh: University of Edinburgh dissertation.

Smith, Norval. 1999. A preliminary account of some aspects of Leurbost Gaelic syllable structure. In Harry van der Hulst \& Nancy A. Ritter (eds.), The syllable: Views and facts, 577-630. Berlin: Mouton de Gruyter.

Sommerfelt, Alf. 1922. Un cas de coup de glotte en irlandais. Bulletin de la Société de Linguistique de Paris 23. 7-14.

Stanton, Juliet \& Sam Zukoff. 2018. Prosodic identity in copy epenthesis: Evidence for a correspondence-based approach. NLLT 36(2). 637-684.

Ternes, Elmar. 1973. The phonemic analysis of Scottish Gaelic, based on the dialect of Applecross, Ross-shire. Hamburg: Helmut Buske.

Ternes, Elmar. 1980. Scottish Gaelic phonemics viewed in a typological perspective. Lingua 52. 73-88.

Ternes, Elmar. 2006. The phonemic analysis of Scottish Gaelic, based on the dialect of Applecross, Ross-shire. Dublin: DIAS 3rd edn.

van Oostendorp, Marc. 2017. Tone, final devoicing, and assimilation in Moresnet. In Kehrein et al. (2017) 237-251.

Watson, Adam \& R. D. Clement. 1981. Aberdeenshire Gaelic. Transactions of the Gaelic Society of Inverness 52. 373-404.

Watson, Joseph. 1974. A Gaelic dialect of N.E. Ross-shire: The vowel system and general remarks. Lochlann 6. 9-90.

Wentworth, Roy G. 2005. Rannsachadh air fòn-eòlas dualchainnt Ghàidhlig Gheàrrloch, Siorrachd Rois. Dublin: DIAS.

Zec, Draga. 1995. Sonority constraints on syllable structure. Phonology 12(1). 85-129. 